\title{
Repatriation Taxes, Repatriation Strategies and Multinational Financial Policy
}

\author{
Rosanne Altshuler \\ Rutgers University \\ and \\ Harry Grubert \\ U.S. Treasury Department
}

This version: July 10, 2000

\begin{abstract}
Several investment-repatriation strategies are added to the standard model of a parent and its affiliate in which the affiliate is located in a low-tax country and is limited to two alternatives: repatriating taxable dividends to the parent or investing in its own real operations. In our model, the subsidiary can invest in passive assets which the parent can borrow against, making any direct taxable flow to the parent unnecessary. The low-tax subsidiary can also use its earnings to invest in a related high-tax affiliate which becomes the vehicle for tax-free repatriations. Alternatively, the low-tax affiliate can be capitalized by equity injections through an upper-tier sibling. This reduces the tax on repatriations from the low-tax subsidiary because taxes at home on foreign source income are based on a blend of the siblings' tax rates. We show analytically how the availability of these strategies can effect real investment in the low-tax subsidiary and throughout the worldwide corporation. We use firm level data for U.S. multinational corporations to test for the importance of these alternative strategies. The evidence is generally consistent with the theory, particularly the "triangular" strategies using related affiliates.
\end{abstract}

JEL Classification: H25, H87

Keywords: multinational, international taxation, investment policy, financial policy, dividend repatriation

Address of corresponding author: Rosanne Altshuler, Department of Economics, Rutgers University, 75 Hamilton Street, New Brunswick, NJ 08901-1248, phone (732) 932-7783, fax (732) 932-7416. E-mail: altshule@rci.rutgers.edu.

Acknowledgements: This paper was prepared for presentation at the Trans-Atlantic Public Economics Seminar, Gerzensee, Switzerland, May, 2000. We are grateful to Mihir Desai, Michael Devereux, and participants at the Trans-Atlantic Public Economics Seminar for helpful comments. We thank Gordon Wilson and Paul Dobbins for providing us with the data files in a convenient form. Any opinions expressed are those of the authors and not of the U.S Treasury Department. 


\section{Introduction}

In spite of the widespread interest in globalization, the literature on the behavior of multinational corporations (MNCs) tends to focus on a limited range of financial flows between foreign affiliates and parents. ${ }^{1}$ In the standard model, the MNC is subject to a credit and deferral tax system at home and typically operates one affiliate in a low-tax country. After capitalizing the affiliate the MNC chooses between direct dividend remittances to the parent and further real investment in the foreign affiliate. Paying dividends is a costly alternative from a tax perspective since these remittances are subject to the higher home country tax rate when received by the parent. However, real investment in the foreign affiliate, which may generate inferior returns relative to investment at home, is only one of many alternatives to direct dividend repatriations. The MNC can engage in a variety of other strategies that have the effect of achieving the equivalent of repatriation without incurring the home country tax on direct repatriations of low-tax income. This paper explores several of these strategies and shows how they can affect the cost of capital both in the low-tax affiliate and in operations elsewhere in the worldwide corporation.

One alternative to direct repatriation and investment in its real operations is investment in passive assets such as Eurodollar deposits. Depending on the size of the interest yield compared to the MNC's equity return, this may be as good as direct remittances. Beyond that, even if after-tax interest rates are low compared to equity returns, the MNC can achieve the complete equivalent of a tax-free direct repatriation if the parent can borrow against the passive assets held by the subsidiary. Once borrowing is an option, direct flows between affiliate and parent are no longer necessary --- the earnings in the low-tax country can support investment at home without bearing the burden of the U.S. corporate tax.

Instead of investing in passive assets or reinvestment, the low-tax affiliate with potentially high taxes on direct repatriations can invest in, or lend to, a related foreign affiliate. This keeps the funds within the worldwide corporation and generates a triangular flow of funds within the MNC. Further, as

\footnotetext{
${ }^{1}$ See the theoretical models in Sinn (1993) and Hartman (1985). The empirical work by Hines and Hubbard (1990), and Altshuler, Newlon and Randolph (1995), also focus primarily on dividend repatriations.
} 
long as the related downstream affiliate is not located in a low-tax country, it can become the vehicle for tax-free repatriation by the low-tax subsidiary. To achieve this result, the low-tax subsidiary invests in the related affiliate which then repatriates all of its income to the parent. Equity injection from the lowtax subsidiary are then used to fund the operations of the related affiliate. As will be explained further below, under credit and deferral tax systems remittances from countries with tax rates greater or equal to home country rates generate no residual home country taxes. This "triangular" strategy therefore allows the parent to effectively convert the income earned in the low-tax subsidiary into high-tax income which can be costlessly repatriated.

Another "triangular" strategy that links the operations of related affiliates is one in which the lowtax affiliate is initially capitalized by an equity injection from an upper-tier subsidiary facing a higher host country tax rate. Then any dividend from the low-tax affiliate up the tier obtains a "blended" higher tax rate for the purpose of tax credits against the home country tax when the dividend reaches the parent.

The first part of the paper adds these alternative strategies to a model of a MNC and its worldwide operations. For a variety of reasons, in this modeling we depart from the conventional arbitrage condition imposed by Sinn (1993) and others which requires that the after-tax interest rate (using the home-country tax rate) is equal to the required return on equity. When considering the standard arbitrage condition, there is the immediate ambiguity about which country's tax rate should be used to compute after-tax interest costs. The standard assumption also seems at variance with the historical facts and, furthermore, eliminates the relevance of several important decisions that a MNC has to make. These include how much to borrow and where to locate its debt. In our model, these become important components of the analysis when we drop the standard arbitrage condition and instead impose a worldwide debt-to-asset constraint.

The analysis shows how broadening the investment, financing, and repatriation strategies available to the MNC can affect real investment in the worldwide corporation. If the low-tax affiliate can achieve the equivalent of tax-free repatriations, it does not have to initially "underinvest," as in Sinn (1993), to obtain the benefits of deferral. The host country tax is not capitalized into the cost of capital in 
the low-tax subsidiary, it is effectively avoided. Furthermore, the strategies considered can affect the cost of capital elsewhere in the MNC. If it is useful to have a high-tax affiliate as a vehicle for low or zero taxes on repatriations, this may increase the value of high-tax investment. Similarly, if investment by the parent at home can enhance its ability to put more tax-deductible borrowing on its own books, investment at home can become more advantageous.

The paper then goes on to test for the empirical importance of the strategies developed in the analytical section. The empirical section uses the U.S. Treasury 1996 data file for MNC parents and their controlled foreign corporation $(\mathrm{CFCs}) .^{2}$ These data provide the CFCs balance sheet, its income statement and various types of transactions with related parties.

The regressions generally provide strong support for the strategies presented in the model. CFCs that face a potentially high-tax on direct repatriations invest a greater amount in related affiliates and extend more loans to them. The empirical analysis also strongly supports the "blending" strategy of sending low-tax income through tiers. CFCs with high repatriation taxes distribute a significantly greater share of their dividends to their foreign affiliates rather than directly to the United States. The results on passive assets are less robust, which may not be surprising in view of the possible inferiority of this strategy outlined in the analytic section.

Finally, the data on CFC debt show that CFCs in high-tax rate countries have much more debt on their books. Furthermore, as CFCs with high potential repatriation taxes accumulate retained earnings, they pay off more local debt, which is another, less costly, version of the passive assets strategy. The retained earnings are not invested exclusively in operating, real assets.

Recent findings on repatriation rates by low-tax CFCs confirm our view that companies can largely escape the burden of potentially high taxes on repatriations. Grubert and Mutti (1999) find that manufacturing subsidiaries in countries with effective tax rates below ten percent only repatriate an average of seven percent of their earnings. Even "mature" CFCs are found to have modest repatriation

\footnotetext{
${ }^{2} \mathrm{~A}$ CFC is a foreign corporation that is at least 50 percent owned by a group of U.S. shareholders each of whom have at least a 10 percent interest in the company.
} 
rates --- the ratio of dividends to current earnings and profits for CFCs incorporated more than fifteen years ago was less than twenty percent. This paper outlines strategies that MNCs can use to achieve this result and suggests that future analytical and empirical work in this area take into consideration the many alternatives to dividend repatriation available to MNCs.

The paper is organized as follows: Section 2 begins with a brief review of the previous literature on the impact of taxes on the investment policies of foreign affiliates. We then introduce a model in which CFCs can invest in passive assets and in related foreign affiliates. There can also be multiple tiers of CFCs through which tax credits are blended upon repatriation to the parent. We model both the standard arbitrage condition and our alternative worldwide debt-to-asset constraint. Under the latter, borrowing against passive assets becomes a viable strategy. We also study how debt and real capital should be allocated across parent and affiliate operations under our worldwide financial constraint. Section 3 contains our empirical results and section 4 briefly summarizes our results and concludes.

\section{The Implications of Investment in Financial Assets}

\subsection{U.S. tax treatment of returns to real and financial investments abroad}

We start by explaining how the U.S. tax code treats the returns to real and financial investments of U.S. multinational corporations. The active business profits of CFCs are generally not subject to U.S. taxation until they are remitted to U.S. parent corporations. As explained below, when repatriations do occur they receive a credit for foreign taxes paid up to the U.S. tax rate. However, this limitation on the credit is on a "basket" or type of income basis. A consequence is that foreign tax credits generated from one type of income (highly taxed dividends, for example) can not be used to offset the U.S. tax liability generated from another type of income (lightly taxed portfolio income, for example).

The deferral of U.S. tax until repatriation has repeatedly been attacked for encouraging U.S. firms to avoid U.S. taxes on foreign income by retaining it abroad in low-tax jurisdictions. Provisions that limit the deferral of foreign profits were added to the tax code in 1962 and have been progressively tightened 
through subsequent tax reforms. In general, these "anti-tax avoidance" provisions (contained in Subpart F of the Internal Revenue Code) limit deferral to earnings from active business investments abroad. ${ }^{3}$ Earnings from financial assets are denied deferral and taxed immediately.

The current taxation of financial income has different consequences for purely passive assets and for investments in equity or debt of other affiliates. Under the "look through" rule for CFCs, income from loans or equity in affiliates in other countries can be in the parent's general (active) income basket if the affiliate is engaged in active operations. This lightly taxed income can then be mixed in with highly taxed dividends for the purpose of the foreign tax credit. Mixing, or "averaging", income subject to high and low tax rates abroad results in lower U.S. tax liabilities on foreign income than would result if the credit were calculated separately for each type of income. In contrast, truly passive income such as Eurodollar interest would be in the parent's passive basket (which will consist mainly of lightly taxed income) and would in all likelihood be subject to full U.S. tax.

Loans and equity in affiliates also have different tax consequences since they differ in the extent to which income has to be currently accrued. While interest has to be paid annually, equity income can be deferred through the non-payment of dividends. Further, when dividends are paid to parents partly out of dividends received from upper-tier affiliates, the repatriation tax due to the U.S. Treasury on the dividend is a "blend" of the tax rates in the high and low tax affiliates. If high-tax affiliates capitalize low-tax affiliates, repatriations of earnings in the low-tax affiliate can be effectively funneled to the parent at a lower repatriation tax cost than if they were paid directly to the parent from the low-tax affiliate. This "multiple tiers" strategy is discussed further in section 2.3 .

Even though they can have differing tax consequences, which will play an important role in our empirical work, passive assets and investments in (or loans to) affiliates are similar in that they offer the CFC alternatives in addition to repatriation to the parent. Both can be used to avoid income from being "trapped" in the CFC's real assets. Furthermore, as we will see, even though passive investments have tax

\footnotetext{
${ }^{3}$ These types of provisions also appear in the tax codes of Germany, Canada, and the U.K., for example.
} 
disadvantages and may yield a low real return compared to "in house" investments, the value of the passive assets can be comparable to investment inside the multinational if the assets can be used to support borrowing by the parent. The remainder of section 2 explores how investing foreign earnings in financial assets can affect the real and financial decisions of multinationals both at home and abroad.

\subsection{The Theoretical Model}

We start with a simple model in which a U.S. parent corporation operates one subsidiary abroad and in which reinvestment in real assets is the only alternative to dividend repatriations. For simplicity, we begin by imposing the standard arbitrage condition that $r=i(1-t)$ where $r$ is the required rate of return on equity at home after-corporate-tax and i is the rate of return on the world capital market. This condition, which is used by Sinn (1993) and others in the international taxation literature, assumes that companies equalize the cost of debt and equity and are indifferent to either form of finance at the margin. Although we find this condition unrealistic and restrictive, we impose it in this section so we can demonstrate how multinational decisions differ when the arbitrage condition is removed and assets held abroad can be used to support borrowing at home.

For simplicity, we start with the two-period model presented in Grubert (1998) in which the basic Hartman-Sinn results can be replicated. The repatriation strategies modeled later in this section are extremely difficult to model in an infinite horizon setting. As we show below, the two-period model captures the impact of our alternative repatriation strategies and worldwide financial constraint on the MNC's investment and financial policy in a transparent way. ${ }^{4}$ In addition, our simple model is a convenient vehicle to use to replicate and compare results from the previous literature, which considered a limited set of repatriation and financial strategies, with results from our more articulated model of MNC behavior.

\footnotetext{
${ }^{4}$ There is at least one drawback to using a two-period model in which production functions are stationary over time. Our model is too simple to capture the benefits of the "multiple tiers" strategy which, as explained below, depends on the presence of growing investment opportunities abroad. The models in Sinn (1993) and Weichenrieder (1996), whose results we extend later in this section, also impose stationary production functions.
} 
In period zero, the foreign affiliate receives an initial equity injection, $\mathrm{K}_{0}$, from the parent. In each subsequent period, the affiliate produces using a standard production function $\mathrm{f}(\mathrm{K})$ with $\mathrm{f}^{\prime}>0$ and $\mathrm{f}^{\prime \prime}<0$. For simplicity, we assume that real capital, $\mathrm{K}$, does not depreciate. In period 1 , the foreign affiliate earns an after-foreign-tax return of $f\left(\mathrm{~K}_{0}\right)\left(1-\mathrm{t}_{\mathrm{f}}\right)$, where $\mathrm{t}_{\mathrm{f}}$ is the statutory corporate tax rate in the host country. At the end of period 1, the parent may retain $(\mathrm{R})$ for reinvestment in the production process or pay dividends (D) which suffer a repatriation tax of $t_{d}$. The parent may also inject additional equity, E, into the affiliate in period 1 . Let $\mathrm{K}_{1}$ equal the total equity transfers held in the affiliate in the beginning of period 2 so that $K_{1}=K_{0}+E$. In period 2, the affiliate generates after-foreign-tax earnings of $f\left(K_{1}+R\right)(1$ $\left.t_{f}\right)$. At the end of period 2, the entire net worth of the affiliate is repatriated: $f\left(K_{1}+R\right)\left(1-t_{f}\right)+K_{1}+R$. With the exception of the repatriation of equity transfers, all cash-flows from the affiliate to the parent are subject to U.S. taxation. At this point it is necessary to explain how the repatriation tax, $t_{d}$, is determined. Consider the taxes paid abroad on a dividend payment of $D: t_{f} D /\left(1-t_{f}\right)+\omega_{f} D$ where $\omega_{f}$ denotes the host country withholding tax rate on dividends. For the purpose of the foreign tax credit, the dividend is "grossed up" by the foreign effective tax rate which may differ from the statutory rate if, for example, the foreign government provides investment incentives such as accelerated depreciation and investment credits. Although we make a distinction between effective and statutory tax rates in our empirical work, we assume (for simplicity) in our theoretical work that effective and statutory tax rates are equal. $^{5}$

The U.S. tax liability on the grossed up dividend payment is $\mathrm{tD} /\left(1-\mathrm{t}_{\mathrm{f}}\right)$, where $\mathrm{t}$ represents the statutory U.S. corporate tax rate. Allowing a foreign tax credit for the taxes paid abroad reduces this home tax liability to $\left(\mathrm{t}-\mathrm{t}_{\mathrm{f}}\right) \mathrm{D} /\left(1-\mathrm{t}_{\mathrm{f}}\right)-\omega_{\mathrm{f}} \mathrm{D}$. The foreign tax credit is limited, however, to the U.S. tax liability on foreign income, $\mathrm{tD} /\left(1-\mathrm{t}_{\mathrm{f}}\right) .{ }^{6}$ If the foreign tax rate exceeds the U.S. rate then there is no residual U.S.

\footnotetext{
${ }^{5}$ Papers by Leechor and Mintz (1993) and Hines (1994) show how investment incentives are affected in situations in which foreign effective tax rates differ from statutory tax rates. Using statutory rates to represent the dividend gross-up rate does not affect our qualitative results.

${ }^{6}$ The limitation on the foreign tax credit operates to some extent on an overall basis. This means that credits accruing from one source of foreign income can often be used to offset U.S. tax on foreign income from another source. As
} 
tax on dividend remittances. Since the parent does not receive a full credit for taxes paid abroad it is said to be in "excess credit." ${ }^{7}$ In this case, the tax cost of dividend repatriations to the multinational (including U.S. and source country taxes) is $t_{d}=\omega_{\mathrm{f}}$. If, on the other hand, the affiliate is located in a low-tax country $\left(t>t_{f}\right.$ and $\left.\left(t-t_{f}\right) /\left(1-t_{f}\right)-\omega_{f}>0\right)$, the parent receives a full credit for taxes paid to the host country and is said to be in "excess limit" or "deficit credits." In this case, the tax cost of dividend repatriations is $t_{d}=(t-$ $\left.\mathrm{t}_{\mathrm{f}}\right) /\left(1-\mathrm{t}_{\mathrm{f}}\right)$. We call this repatriation tax the "excess limit tax price" in our empirical work.

Optimal repatriation strategies, financial policy, and investment decisions depend on whether the parent has excess foreign tax credits. It is therefore necessary to examine optimal policies separately for parents in excess limit and excess credit positions. We focus on the case in which the parent is in a (stationary) excess limitation position in the next section and the (stationary) excess credit case in section $2.4^{8}$

\subsection{Incentives for parents in excess limitation positions}

The parent's problem is to choose $\mathrm{K}_{0}, \mathrm{~K}_{1}$, and $\mathrm{R}$ to maximize the value of equity after host and home country tax subject to the cash-flow constraint given below:

$$
\begin{gathered}
\max -K_{0}+(1+r)^{-1}\left[D\left(1-t_{d}\right)-E\right]+(1+r)^{-2}\left[f\left(K_{1}+R\right)\left(1-t_{f}\right)\left(1-t_{d}\right)+K_{1}+R\left(1-t_{d}\right)\right] \\
\text { subject to } D=f\left(K_{0}\right)\left(1-t_{f}\right)-R .
\end{gathered}
$$

noted earlier in the text, cross-crediting is only possible if the income is in the same foreign tax credit basket.

${ }^{7}$ Under current law, excess credits can be carried back to offset any U.S. tax payments on foreign-source income made in the previous two years. Credits may also be carried forward without interest and used to offset U.S. tax liability in the following five years. Note that the tax cost that we use in our theoretical and empirical work is a "current" remittance cost that does not include an adjustment for foreign tax credit carrybacks or carryforwards. We abstract from the possibility that investment and financial policies may cause parents to switch credit positions to focus on the impact of alternatives to repatriation on economic decisions. Altshuler and Fulghieri (1994) consider how investment incentives change as parents switch into and out of excess credit positions.

${ }^{8}$ Since, up to this point, we have assumed that the parent owns only one subsidiary abroad its foreign tax credit position depends only on host country taxes in the subsidiary. However, if the parent has more than one affiliate, or if it receives different types of income from operations abroad (such as royalty or interest income), its foreign tax credit position in any "basket" of income will depend on its average tax rate of foreign source income. The parent is in an excess limitation position if its average tax rate on foreign source income is less than the U.S. rate and in an excess credit position otherwise. 
Before solving this problem, we compare the impact of equity injections and retentions on the maximand. A dollar of retentions at the expense of an equity injection increases the after-tax value of equity by $\mathrm{rt}_{\mathrm{d} .}{ }^{9}$ Thus, retentions dominate equity injections $(\mathrm{R}>0$ and $\mathrm{E}=0)$ if repatriation taxes are positive (when $\mathrm{t}>\mathrm{t}_{\mathrm{f}}$ ). Consider the usual case in the literature in which the subsidiary is located in a low-tax country relative to the home country $\left(\mathrm{t}>\mathrm{t}_{\mathrm{f}}\right)$. The first-order conditions for this problem result in the following investment rules:

$$
\mathrm{f}^{\prime}\left(\mathrm{K}_{1}+\mathrm{R}\right)\left(1-\mathrm{t}_{\mathrm{f}}\right)=\mathrm{r} \quad \text { with respect to } \mathrm{R}
$$

$$
\mathrm{f}^{\prime}\left(\mathrm{K}_{0}\right)\left(1-\mathrm{t}_{\mathrm{f}}\right)\left(1-\mathrm{t}_{\mathrm{d}}\right)=1+\mathrm{r}-\left(\frac{1+\mathrm{r}\left(1-\mathrm{t}_{\mathrm{d}}\right)}{1+\mathrm{r}}\right) \quad \text { with respect to } \mathrm{K}_{0}
$$

The first condition is the standard Hartman-Sinn result: the capital stock in the second period is a function of the foreign tax rate and not the repatriation tax $t_{d}$. The second condition indicates that repatriation taxes do play a role in determining the optimal equity injection. If the affiliate is in a low-tax country $\left(t>t_{f}\right)$, the parent injects less capital than it would under an exemption or territorial tax system since it can obtain the benefits of deferral until it reaches the "target" capital stock. The initial equity injection increases as the repatriation tax and, consequently, the benefits of deferral decrease.

If the affiliate is located in a high-tax country and we continue to assume that the parent is in excess limitation (due to the presence of low-tax remittances such as royalties, for example, from elsewhere in the MNC), the investment rules are altered since there is no longer an advantage to deferral. Optimal retentions are zero and the first-order condition with respect to both $\mathrm{K}_{0}$ and $\mathrm{K}_{1}$ is:

$$
\mathrm{f}^{\prime}\left(\mathrm{K}_{0}\right)(1-\mathrm{t})=\mathrm{f}^{\prime}\left(\mathrm{K}_{1}\right)(1-\mathrm{t})=\mathrm{r}
$$

The high-tax subsidiary is immediately capitalized to its steady-state.

\footnotetext{
${ }^{9}$ To see this compare the partial derivatives of the maximand with respect to $\mathrm{E}$ and $\mathrm{R}$. $\partial \bullet / \partial \mathrm{R}>(<) \partial \bullet / \partial \mathrm{E} \Leftrightarrow \mathrm{t}>(<) \mathrm{t}_{\mathrm{f}}$.
} 


\section{Investing in Passive Assets as an Alternative to Repatriation}

Now that we have reproduced the standard Hartman-Sinn results, we study the implications of allowing parents to reinvest active earnings in the world capital market. Weichenrieder (1996) extends the Hartman-Sinn model to consider how the size and growth of foreign affiliates is affected by "anti-tax avoidance" rules that limit deferral to earnings on active investments abroad. We present a simple version of his result here to compare with the results we obtain when we allow for additional alternatives to repatriation and drop the standard arbitrage condition.

In our new model, at the end of period 1, the parent decides between reinvestment in real capital, dividends, and investment in passive assets $(\mathrm{P})$ which earn an after-foreign-tax return of $\mathrm{i}\left(1-\mathrm{t}_{\mathrm{f}}\right)$. Although earnings from passive assets are taxed as if they were remitted as dividends, the reinvested foreign earnings are not taxed until repatriated. The parent's problem now becomes:

Choose $\mathrm{K}_{0}, \mathrm{~K}_{1}, \mathrm{R}, \mathrm{D}$, and $\mathrm{P}$ to

$$
\begin{gathered}
\operatorname{maximize}-K_{0}+(1+r)^{-1}\left[D\left(1-t_{d}\right)-E\right]+(1+r)^{-2}\left[f\left(K_{1}+R\right)\left(1-t_{f}\right)\left(1-t_{d}\right)+K_{1}+R\left(1-t_{d}\right)+\left(1+i\left(1-t_{f}\right)\right) P\left(1-t_{d}\right)\right] \\
\text { subject to } D=f\left(K_{0}\right)\left(1-t_{f}\right)-R-P .
\end{gathered}
$$

To simplify the analysis, before solving the problem we establish the conditions under which the affiliate should pay dividends at the expense of investment in passive assets. On one hand, an additional dollar of dividends generates $\left(1-\mathrm{t}_{\mathrm{d}}\right) /(1+\mathrm{r})$ after taxes. On the other hand, the after-tax return of a dollar invested in passive assets at the expense of dividends is $\left(1+i\left(1-t_{f}\right)\right)\left(1-t_{d}\right) /(1+r)^{2}$. As long as the net of tax interest rate earned abroad, $\mathrm{i}\left(1-\mathrm{t}_{\mathrm{f}}\right)$, exceeds the required rate of return on equity, $\mathrm{r}$, investment in passive assets dominates dividend payments. Since we have assumed that $r$ is equal to $\mathrm{i}(1-\mathrm{t})$, only affiliates in low-tax countries $\left(\mathrm{t}>\mathrm{t}_{\mathrm{f}}\right)$ should invest in passive assets and pay no dividends. ${ }^{10}$ This result is a direct consequence of the tax rules that allow deferral on reinvested foreign earnings.

We start by assuming that the foreign affiliate is located in a low-tax country and therefore passive assets dominate dividends. Solving the parent's maximization problem for the optimal value of

\footnotetext{
${ }^{10}$ As Hines and Rice (1994) point out, this result may also hold when interest rates differ across countries. The necessary condition is that the after-foreign tax interest rate exceeds the after-tax interest rate at home.
} 
$\mathrm{K}_{0}, \mathrm{~K}_{1}, \mathrm{R}$ and $\mathrm{P}$ given that $\mathrm{D}=0$ leaves us with three possible cases: (i) $\mathrm{R}=0$ and $\mathrm{P}>0$, (ii) $\mathrm{R}>0$ and $\mathrm{P}=0$, and (iii) $\mathrm{R}>0$ and $\mathrm{P}>0$. However, given that the affiliate is located in a low-tax country and our standard assumptions on the production function, only the first case may obtain. ${ }^{11}$ Thus, maximizing the value of equity held in the affiliate requires that all returns from real investment at the end of period 1 be reinvested in passive assets. The first-order conditions for investment with respect to $\mathrm{K}_{0}$ and $\mathrm{K}_{1}$ are:

$$
\mathrm{f}^{\prime}\left(\mathrm{K}_{0}\right)(1-\mathrm{t})=\mathrm{f}^{\prime}\left(\mathrm{K}_{1}\right)(1-\mathrm{t})=\mathrm{r}\left(\frac{2+\mathrm{r}}{2+\mathrm{i}\left(1-\mathrm{t}_{\mathrm{f}}\right)}\right)
$$

The parent immediately capitalizes the low-tax affiliate to the steady-state level of capital $\mathrm{K}^{*}$ (where $\mathrm{K}^{*}=\mathrm{K}_{0} *=\mathrm{K}_{1} *$ and $*$ denotes an optimum). ${ }^{12}$

The investment rule indicates that in the presence of passive assets, there is no longer an incentive to "underinvest" in the foreign affiliate. ${ }^{13}$ Unlike in the Hartman-Sinn model, equity is no longer "trapped" in the foreign affiliate since it may be used to invest in the world capital market. The affiliate obtains the benefits of deferral on active income by investing the income in passive assets. It is never optimal to reinvest any first period earnings in real foreign assets because the CFC can always earn $\mathrm{i}=$ $\mathrm{r} /(1-\mathrm{t})$ on passive assets. Note that the initial equity injection is higher than in the Hartman-Sinn case since the multinational does not have to "underinvest" to obtain the benefits of deferral. Finally, since $P=f\left(K^{*}\right)\left(1-t_{f}\right)$, optimal investment in passive assets increases with $t_{f}\left(\right.$ for $\left.t_{f}<t\right)$.

With a finite horizon and ultimate repatriation of all income, the cost of capital depends on the closure date of the firm since it determines the benefits of deferral. However, in an infinite horizon

\footnotetext{
${ }^{11}$ Taking partial derivatives of the value function with respect to $\mathrm{R}$ and $\mathrm{P}$ shows that retentions dominate passive assets (case ii) only if the marginal product of capital in period $2\left(f^{\prime}\left(K_{1}+R\right)\right)$ exceeds i. Solving for optimal $K_{0}$ and $R$ and imposing concavity of $f$ shows that $\mathrm{f}^{\prime}\left(\mathrm{K}_{1}+\mathrm{R}\right)>\mathrm{i}$ only if $\mathrm{t}<\mathrm{t}_{\mathrm{f}}$. Thus, case (ii) can not exist when the affiliate is located in a low-tax country. Case (iii) requires that $\mathrm{f}^{\prime}\left(\mathrm{K}_{1}+\mathrm{R}\right)=\mathrm{i}$. However, when $\mathrm{P}=0$ and $\mathrm{R}=\mathrm{f}\left(\mathrm{K}_{0}\right)\left(1-\mathrm{t}_{\mathrm{f}}\right)$, if $\mathrm{f}$ is concave, $\mathrm{f}^{\prime}\left(\mathrm{K}_{1}+\mathrm{R}\right) \neq \mathrm{i}$ when $\mathrm{t}>\mathrm{t}_{\mathrm{f}}$.

${ }^{12}$ To better understand the first-order condition we rearrange it as follows: $\mathrm{f}^{\prime}\left(\mathrm{K}^{*}\right)(1-\mathrm{t})\left(2+\mathrm{i}\left(1-\mathrm{t}_{\mathrm{f}}\right)\right)=-1+(1+\mathrm{r})+(1+\mathrm{r})(1+\mathrm{r}-1)=\mathrm{r}(2+\mathrm{r})$.

The left-hand side of the equation is the after-tax marginal benefit of investment. The right-hand side represents the marginal cost: the foregone return on the equity injection (after-tax).

${ }^{13}$ Although Hines (1994) does not explicitly model the option of investing in passive assets, he also concludes that there is no incentive to underinvest if firms can freely borrow and lend at world interest rates.
} 
setting neither equity or principal would be repatriated. As a result, the 2's would be eliminated from both sides of equation (4) and the Hartman-Sinn result $\left[\mathrm{f}^{\prime}\left(\mathrm{K}^{*}\right)=\mathrm{r} /\left(1-\mathrm{t}_{\mathrm{f}}\right)\right]$ would obtain. ${ }^{14}$ From the beginning, the CFC invests in real assets as if foreign income were exempt from U.S. taxation because it can always earn a normal return on its passive retained assets. This result is derived using a infinite period dynamic optimization model in Weichenrieder (1996).

\section{Investing in a High-Tax Affiliate as an Alternative to Repatriation}

Even in a traditional all equity model the multinational can achieve the same results without investing in purely passive assets if it also has another CFC in a country with a tax rate at least equal to the U.S. (home country) rate. ${ }^{15}$ Consider, therefore, a multinational that can invest in two locations, one with a low corporate tax rate relative to the U.S. rate $\left(t_{L}\right.$ where $\left.t_{L}<t\right)$ and one with a high corporate tax rate relative to the U.S. rate $\left(t_{H}\right.$ where $\left.t_{H}>t\right)$. As before, we assume that the parent is in an excess limitation foreign tax credit position. The repatriation tax for remittances from the low (high) -tax country is denoted $t_{L, d}\left(t_{H, d}\right)$. Let the production function in the high-tax affiliate be $h(K)$ with $h^{\prime}>0$ and $\mathrm{h}^{\prime \prime}<0$ and $\mathrm{f}(\mathrm{K})$ be the production function in the low-tax affiliate (with $\mathrm{f}^{\prime}>0$ and $\mathrm{f}^{\prime \prime}<0$ as before). Let $\mathrm{K}_{\mathrm{H}, 0}$ equal the initial equity injection in the high-tax affiliate and $\mathrm{K}_{\mathrm{L}, 0}$ be defined similarly for the low-tax affiliate. $\mathrm{E}_{\mathrm{H}}$ and $\mathrm{E}_{\mathrm{L}}$ denote, respectively, equity injections at the end of period one from the parent to the high-tax and low-tax subsidiary. Finally, $\mathrm{K}_{\mathrm{H}, 1}=\mathrm{K}_{\mathrm{H}, 0}+\mathrm{E}_{\mathrm{H}}$ and $\mathrm{K}_{\mathrm{L}, 1}=\mathrm{K}_{\mathrm{L}, 0}+\mathrm{E}_{\mathrm{L}}$.

We now allow the parent the option of investing profits earned abroad in other related affiliates. Specifically, at the end of the first period, we allow the low-tax subsidiary to invest in the high-tax subsidiary and vice-versa. As explained further below, in a two-period model investment in the high-tax subsidiary using funds from the low-tax subsidiary (the "triangular" strategy) will dominate capitalizing

\footnotetext{
${ }^{14}$ As the time horizon increases, the present value of the unrepatriated capital goes to zero.

${ }^{15}$ Using a similar dataset to ours for 1986, Altshuler and Newlon (1993) find that almost three-quarters of the parents had CFCs in both high- and low-tax countries.
} 
the low-tax subsidiary using funds from the high-tax subsidiary (the "multiple tiers" strategy).

Consequently, we start by considering investment rules for the "triangular" case.

At the end of the first and second period, as before, the parent may receive dividend and equity repatriations from its foreign subsidiaries. Note that neither of these repatriations from the high-tax subsidiary results in a positive U.S. residual tax. The high-tax earnings receive a foreign tax credit equal to foreign tax payments since the parent is in an excess limitation position, and the initial equity can be repaid without any tax as long as there are no accumulated earnings in the high-tax subsidiary.

It is necessary to be precise about the U.S. taxation of the equity and profits held in the low-tax $\mathrm{CFC}$ at the end of the second period. It is taxed on all of its accumulated earnings and profits including its investment in the high-tax affiliate. When the low-tax subsidiary receives a dividend from the high-tax subsidiary at the end of period two, there will be no tax owing in the low-tax country because dividends are either exempt from taxation or shielded by credits. When the income is finally repatriated by the lowtax subsidiary to the U.S., the dividend will carry the lower tier taxes paid (in the high-tax subsidiary) as a credit. ${ }^{16}$ This makes the triangular case entirely equivalent to the passive assets case in the previous section.

Let $\mathrm{H}$ equal the investment in the high-tax subsidiary from earnings in the low-tax subsidiary. (Note that in our simple two-period model, the parent will be indifferent between transmitting capital from the low-tax CFC to the high-tax CFC in the form of a loan or an investment.) The formal problem faced by the parent is to choose an investment and repatriation strategy $\left(\mathrm{K}_{\mathrm{L}, 0}, \mathrm{~K}_{\mathrm{L}, 1}, \mathrm{~K}_{\mathrm{H}, 0}, \mathrm{~K}_{\mathrm{H}, 1}, \mathrm{R}_{\mathrm{L}}, \mathrm{R}_{\mathrm{H}}, \mathrm{D}_{\mathrm{L}}\right.$, $\mathrm{D}_{\mathrm{H}}$ and $\mathrm{H}$ ) to maximize the value of equity held in both the low-tax and high-tax subsidiary subject to the cash-flow and investment constraints given below:

$$
\begin{gathered}
\text { maximize }-\mathrm{K}_{\mathrm{L}, 0}+(1+\mathrm{r})^{-1}\left[\mathrm{D}_{\mathrm{L}}\left(1-\mathrm{t}_{\mathrm{L}, \mathrm{d}}\right)-\mathrm{E}_{\mathrm{L}}\right] \\
+(1+\mathrm{r})^{-2}\left[\mathrm{f}\left(\mathrm{K}_{\mathrm{L}, 1}+\mathrm{R}_{\mathrm{L}}\right)\left(1-\mathrm{t}_{\mathrm{L}}\right)\left(1-\mathrm{t}_{\mathrm{L}, \mathrm{d}}\right)+\mathrm{K}_{\mathrm{L}, 1}+\mathrm{R}_{\mathrm{L}}\left(1-\mathrm{t}_{\mathrm{L}, \mathrm{d}}\right)+\mathrm{H}\left(1-\mathrm{t}_{\mathrm{L}, \mathrm{d}}\right)\right] \\
-\mathrm{K}_{\mathrm{H}, 0}+(1+\mathrm{r})^{-1}\left[\mathrm{D}_{\mathrm{H}}\left(1-\mathrm{t}_{\mathrm{H}, \mathrm{d}}\right)-\mathrm{E}_{\mathrm{H}}+\mathrm{H}\right]
\end{gathered}
$$

\footnotetext{
${ }^{16}$ Under current U.S. tax law, taxes paid up through six tiers of affiliates can be credited against U.S. taxes on foreign source income through the foreign tax credit mechanism.
} 


$$
\begin{gathered}
+(1+r)^{-2}\left[h\left(K_{H, 1}+R_{H}\right)\left(1-t_{H}\right)\left(1-t_{H, d}\right)+K_{H, 1}+R_{H}-H\right] \\
\text { subject to } D_{L}=f\left(K_{L, 0}\right)\left(1-t_{L}\right)-R_{L}-H . \\
D_{H}=h\left(K_{H, 0}\right)\left(1-t_{H}\right)-R_{H} \\
H \leq K_{H, 1} \text { and } H \leq f\left(K_{L, 0}\right)\left(1-t_{L}\right)
\end{gathered}
$$

The first two lines give the value of equity associated with the low-tax subsidiary and the second two give the value of equity held in the high-tax subsidiary. Along with usual cash-flow constraints, the parent now faces two additional constraints: $\mathrm{H}$ can not exceed total equity held in the high-tax subsidiary in the second period or after-host-country-tax earnings in the low-tax subsidiary at the end of period one.

This maximization problem can be simplified by noting from the previous section that equity injections dominate reinvestment of profits in the high-tax country so that $R_{H}=0$ and therefore $D_{H}=$ $\mathrm{h}\left(\mathrm{K}_{\mathrm{H}, 0}\right)\left(1-\mathrm{t}_{\mathrm{H}}\right)$. The firm's maximization problem can now be written as:

$$
\begin{gathered}
\text { choose } \mathrm{K}_{\mathrm{L}, 0}, \mathrm{~K}_{\mathrm{L}, 1}, \mathrm{~K}_{\mathrm{H}, 0}, \mathrm{~K}_{\mathrm{H}, 1}, \mathrm{H} \text { and } \mathrm{R}_{\mathrm{L}} \\
\text { to maximize }-\left(\mathrm{K}_{\mathrm{L}, 0}+\mathrm{K}_{\mathrm{H}, 0}\right)+(1+\mathrm{r})^{-1}\left[\mathrm{~h}\left(\mathrm{~K}_{\mathrm{H}, 0}\right)\left(1-\mathrm{t}_{\mathrm{H}}\right)\left(1-\mathrm{t}_{\mathrm{H}, \mathrm{d}}\right)-\mathrm{E}_{\mathrm{H}}+\mathrm{H}\right] \\
+(1+\mathrm{r})^{-2}\left[\mathrm{~h}\left(\mathrm{~K}_{\mathrm{H}, 1}\right)\left(1-\mathrm{t}_{\mathrm{H}}\right)\left(1-\mathrm{t}_{\mathrm{H}, \mathrm{d}}\right)+\mathrm{K}_{\mathrm{H}, 1}-\mathrm{H}\right] \\
+(1+\mathrm{r})^{-1}\left[\mathrm{D}_{\mathrm{L}}\left(1-\mathrm{t}_{\mathrm{L}, \mathrm{d}}\right)-\mathrm{E}_{\mathrm{L}}\right]+(1+\mathrm{r})^{-2}\left[\mathrm{f}\left(\mathrm{K}_{\mathrm{L}, 1}+\mathrm{R}_{\mathrm{L}}\right)\left(1-\mathrm{t}_{\mathrm{L}}\right)\left(1-\mathrm{t}_{\mathrm{L}, \mathrm{d}}\right)+\mathrm{K}_{\mathrm{L}, 1}+\mathrm{R}_{\mathrm{L}}\left(1-\mathrm{t}_{\mathrm{d}}\right)+\mathrm{H}\left(1-\mathrm{t}_{\mathrm{L}, \mathrm{d}}\right)\right] \\
\text { subject to } \mathrm{D}_{\mathrm{L}}=\mathrm{f}\left(\mathrm{K}_{\mathrm{L}, 0}\right)\left(1-\mathrm{t}_{\mathrm{L}}\right)-\mathrm{R}_{\mathrm{L}}-\mathrm{H}, \\
\mathrm{H} \leq \mathrm{K}_{\mathrm{H}, 1} \text { and } \mathrm{H} \leq \mathrm{f}\left(\mathrm{K}_{\mathrm{L}, 0}\right)\left(1-\mathrm{t}_{\mathrm{L}}\right)
\end{gathered}
$$

There are two regions of solutions to this maximization problem depending on which of the $\mathrm{H}$ constraints bind. ${ }^{17}$ Consider first the case in which the high-tax subsidiary is "large" relative to after-tax earnings in the low-tax subsidiary: $\mathrm{H}<\mathrm{K}_{\mathrm{H}, 1}$ and $\mathrm{H}=\mathrm{f}\left(\mathrm{K}_{\mathrm{L}, 0}\right)\left(1-\mathrm{t}_{\mathrm{L}}\right)$. The first-order conditions for investment are:

$$
\begin{array}{ll}
f^{\prime}\left(K_{L, 0}\right)(1-t)=f^{\prime}\left(K_{L, 1}\right)(1-t)=r\left(\frac{2+r}{2+i\left(1-t_{L}\right)}\right) & \text { with respect to } K_{L, 0} \text { and } K_{L, 1} \\
h^{\prime}\left(K_{H, 0}\right)(1-t)=h^{\prime}\left(K_{H, 1}\right)(1-t)=r & \text { with respect to } K_{H, 0} \text { and } K_{H, 1}
\end{array}
$$

\footnotetext{
${ }^{17}$ We ignore the knife-edge case in which both bind.
} 
As in the passive asset case, the parent need not underinvest in the low-tax CFC in order to get the benefits of deferral because it can always obtain a "normal" after-tax return $r$ on its earnings by using its high-tax affiliate as a vehicle for making tax-free repatriations. Note that optimal investment in the lowtax subsidiary is at the same level as in the "passive assets only" case (the investment rules given in equations (4) and (5) are identical for $t_{f}=t_{L}$ ). In a longer horizon in which the high-tax affiliate's final payback of initial equity is in the distant future the first-order condition is again the Hartman-Sinn rule: $\mathrm{f}^{\prime}\left(\mathrm{K}^{*}\right)=\mathrm{r} /\left(1-\mathrm{t}_{\mathrm{L}}\right)^{18}$

Turning to equation (6) we see that the triangular strategy has no effect on the cost of capital in the high-tax subsidiary relative to our original case in which dividends were the only alternative to reinvestment (see equation 3). Since the parent is in excess limitation it faces the U.S. tax rate on investment in high-tax affiliates abroad.

It is important to note that the "triangular" strategy is different from the usual "cross-crediting" or "averaging" case. In the latter, the two subsidiaries make simultaneously direct repatriations to the parent and the dividends from the high-tax subsidiary shield the dividends from the low-tax subsidiary from U.S. taxation upon repatriation. While this strategy may leave a residual U.S. tax, there would not be one in the triangular strategy.

One way of clearly distinguishing the consequences of "cross-crediting" from our triangular case is to consider a situation in which the "high-tax" subsidiary is located in a country with a corporate tax rate just equal to the U.S. corporate rate. In this scenario direct dividends from the low-tax subsidiary generate residual U.S. taxes regardless of whether the "high-tax" subsidiary simultaneously makes a dividend payment to the parent. This is because the direct dividend from the "high-tax" subsidiary generates no excess credits to absorb the residual U.S. tax liability on the remittance from the low-tax subsidiary since the tax rate is the same in the high-tax subsidiary as in the U.S. As a result, remittances

\footnotetext{
${ }^{18}$ Eventually the high-tax affiliate will have repaid all of its initial equity injection, so the infinite time horizon solution is not quite applicable. In that case, the solution is similar to the finite horizon, passive assets, model in the previous section. Still, in a more realistic case where the subsidiaries have growing demands for capital because of economic growth or change in technology, the final payback of the high-tax subsidiary's initial equity may be in the distant future.
} 
of earnings from the low-tax subsidiary incur repatriation taxes. The triangular strategy, on the other hand, allows the parent to effectively avoid repatriation taxes on returns from investment in the low-tax subsidiary.

What if the parent is constrained in its use of the triangular strategy by the optimal size of the high-tax subsidiary? In this case the high-tax subsidiary is "small" relative to after-tax earnings in the low-tax subsidiary: $\mathrm{H}=\mathrm{K}_{\mathrm{H}, 1}$ and $\mathrm{H}<\mathrm{f}\left(\mathrm{K}_{\mathrm{L}, 0}\right)\left(1-\mathrm{t}_{\mathrm{L}}\right)$. The first-order conditions for investment are:

$$
\mathrm{f}^{\prime}\left(\mathrm{K}_{\mathrm{L}, 1}+\mathrm{R}_{\mathrm{L}}\right)\left(1-\mathrm{t}_{\mathrm{L}}\right)=\mathrm{r} \quad \text { with respect to } \mathrm{R}_{\mathrm{L}}
$$

$$
\begin{array}{ll}
f^{\prime}\left(K_{L, 0}\right)\left(1-t_{L}\right)\left(1-t_{L, d}\right)=1+r-\left(\frac{1+r\left(1-t_{L, d}\right)}{1+r}\right) & \text { with respect to } K_{L, 0} \\
h^{\prime}\left(K_{H, 1}\right)(1-t)=r\left(1-t_{L, d}\right) & \text { with respect to } K_{H, 1} \\
h^{\prime}\left(K_{H, 0}\right)(1-t)=r & \text { with respect to } K_{H, 0}
\end{array}
$$

The parent is unable to avoid the repatriation tax on the returns to marginal investment in the low-tax subsidiary and, as a result, the parent underinvests $\left(\mathrm{R}_{\mathrm{L}}>0\right) .{ }^{19}$ Equity is trapped in the low-tax subsidiary due to the positive repatriation tax. In a sense, equity is also trapped in the high-tax subsidiary. Equation (9) shows that cost of capital in the high-tax subsidiary is lower in the second period as a result of the repatriation benefit of using the triangular strategy! The parent would not be willing to absorb a low after-tax return in the low-tax subsidiary when it could be obtaining a better after-tax return in the hightax affiliate. This leads to a lowered cost of capital and higher investment relative to the first period in the high-tax affiliate. Finally, since the size of the original equity injection in the high-tax subsidiary does not effect the parent's use of the triangular repatriation strategy the cost of capital is initially the standard one (see equation 10).

19 As in the Hartman-Sinn world, retentions dominate equity injections in this scenario $\left(E_{L}=0\right.$ and $\left.R_{L}>0\right)$. 


\section{Using Multiple Tiers to Reduce Repatriation Taxes}

Up to this point we have assumed that parents capitalize their affiliates directly. In fact, it is possible that there will be situations in which the parent's optimal strategy is to first inject additional equity to a high-tax subsidiary which then invests the equity in a low-tax sibling. As mentioned above, the advantage of this strategy is that the low-tax affiliate can repatriate earnings to the parent through the high-tax affiliate with a lower "blended" repatriation tax rate. Specifically, the "gross up" tax rate that determines the credit on the dividends passing through the high-tax subsidiary is:

Taxes paid by high-tax subsidiary + pro-rata share of taxes paid by low-tax subsidiary . High-tax earnings and profits plus pro-rata share of low-tax earnings and profits

We do not include this strategy as an explicit option in the theoretical model because the triangular strategy that we considered would always dominate in a two-period, stationary investment function model where it is available. In that strategy, in which the low-tax subsidiary invests in the hightax subsidiary, the MNC can achieve a fully tax-free repatriation and all potential high-tax credits are used because the high-tax affiliate repatriates all of its income. The "blending" strategy depends on the high-tax affiliate not repatriating all of its income. If it did, the U.S. tax on the combined repatriations would be the same as if the two entities just repatriated directly to the parent. All available credits would be used.

But in a more general multi-period model in which investment opportunities are growing over time, the "multiple tiers" strategy may be preferable. There is the possibility that the "triangular" strategy analyzed above cannot be maintained indefinitely because eventually the low-tax subsidiary would own 100 percent of its high-tax sibling. Furthermore, in a growing world, the high-tax subsidiary would, given a constant cost of capital, increase its capital stock over time anyway. The low-tax subsidiary can, therefore, lower its repatriation tax by "borrowing" credits from the high-tax subsidiary which doesn't need them because it would not choose to repatriate all of its income. ${ }^{20}$ This strategy can also continue to be used in the long run because it does not run into the 100 percent ownership constraint.

${ }^{20}$ This "borrowing of credits" strategy may be optimal even in a two-period, stationary investment function model if 
A very clear case which illustrates the benefits of the blending strategy is one in which the tax rate in the high-tax affiliate's location is just equal to the U.S. rate. Then there are no spillover credits generated by the high-tax affiliate's dividends and it loses nothing by retaining its income to finance its own growth. Routing the low-tax income through the high-tax subsidiary results in a pure net gain. ${ }^{21}$ Of course, rather than having to choose one strategy or the other, MNCs may engage in more complex schemes, such as starting with the "triangular" investment strategy and then switching to the "multiple tiers" strategy.

\section{Dropping the standard arbitrage condition}

Now that we have examined the alternative repatriation strategies we consider how investment and financial policy are affected when we drop the standard arbitrage condition imposed in the previous literature. The standard arbitrage condition eliminates many interesting aspects of companies' financial behavior. It also raises several conceptual issues and seems clearly inconsistent with empirical evidence. First, the arbitrage condition assumes that the worldwide company can use 100 percent debt finance at the margin without increasing its financing costs. ${ }^{22}$ Second, it assumes that only companies can arbitrage after-tax costs while shareholders passively accept any difference in after-personal-tax returns on debt and equity. And finally, it implies that the real interest rate is higher than the after-corporate-tax return on equity, in contrast to the historically large discrepancy in the opposite direction.

no tax-free repatriation options are available. Routing a low-tax dividend through the high-tax subsidiary increases the latter's repatriation tax. The high-tax subsidiary, therefore, retains more after the first period. But the accelerated use of the credits by the low-tax subsidiary may be efficient if it has fewer investment opportunities in the second period than the high-tax subsidiary.

${ }^{21}$ Under subpart F of the U.S. tax code, the payment of the dividend from the low-tax subsidiary to its high-tax upper tier owner will result in a current U.S. tax on the dividend unless the blended tax rate is at least equal to 90 percent of the U.S. rate.

${ }^{22}$ There is a large finance literature based on the premise that the risk of bankruptcy makes borrowing costs rise as the company's debt increases as a percent of its total capitalization. There is also a large literature on debt "rationing" because of asymmetric information (see for example, Stiglitz and Weiss 1981). 
One simple way of departing from the standard arbitrage condition and reflecting what appears to be the reality of the capital market is simply to assume that the company faces a worldwide constraint, L, on how large its debt can be as a percent of its worldwide assets. ${ }^{23}$ This is similar to assuming a rising cost of debt finance. We will also assume that $\mathrm{i}(1-\mathrm{t})$ is less than $\mathrm{r}$, i.e., that debt is a cheap source of finance in the U.S. and that $\mathrm{i}\left(1-\mathrm{t}_{\mathrm{L}}\right)>\mathrm{r}$. Since the parent is in an excess limitation position, it will receive the same interest deductions after host and home country tax in the high-tax country and at home. As a result, the parent is indifferent between issuing debt in these two locations. However, it is never optimal to borrow in the low-tax country since $\mathrm{i}\left(1-\mathrm{t}_{\mathrm{L}}\right)>\mathrm{r}$.

At this point it is interesting to consider how the debt constraint arises. The constraint states that lenders are unwilling to go beyond a certain point in financing the company's assets. This is presumably because the company's real assets and operations are risky. But if some part of the worldwide company has a large balance in Eurodollar deposits, its creditors know that these financial assets can easily be liquidated in order to pay off loans elsewhere in the company if that becomes necessary. The Eurodollar deposits can be used explicitly for "back to back" loans or as collateral, or informally to give creditors a different view of the true risk in the company.

One way to express the role of passive liquid assets in potentially increasing the company's borrowing power is to net passive assets from debt for the purposes of the debt to asset constraint. That is, creditors will base their evaluation of a company's risk of default by looking at its net debt in relation to its operating assets. The netting is done on a worldwide basis because passive assets in one part of the multinational can back loans elsewhere. ${ }^{24}$

\footnotetext{
${ }^{23}$ At this point, it is not necessary to know exactly how $\mathrm{L}$ is determined. For example, one question that we address in section 3 is, for a given worldwide L, how are debt and assets distributed in the worldwide multinational. In the $\mathrm{r}=\mathrm{i}(1-$ t) arbitrage condition world, the foreign subsidiary and the parent can both have 100 percent (external) debt at the same time. In the constraint we now impose, the foreign subsidiary can only issue more debt (for given capital stocks) if the parent borrows less.

${ }^{24}$ One alternative possibility is that lenders only net the after-tax amount of passive assets if repatriation becomes necessary to pay off loans. This may, of course, affect some of the results in this section since investing in passive assets would become less desirable than investing in the high-tax subsidiary (the triangular strategy). The triangular strategy will generally dominate holding passive assets. However, when the parent is constrained in its use of this strategy by the size of equity held in the high-tax subsidiary $\left(\mathrm{H}=\mathrm{K}_{\mathrm{H}, 1}\right)$, holding passive assets may become attractive.
} 
We have used the simplifying assumption of a worldwide borrowing constraint on the grounds that (a) creditors will put limits on the company's leverage because of potential bankruptcy costs, and (b) potential creditors considering a loan to an affiliate in one country will look at the MNC's worldwide debts in assessing the riskiness of the loan. In other words, the worldwide assets could be used to support a particular unit in distress. But as Desai (1997) notes "the jurisdictional issues raised by a multinational insolvency remain largely unresolved." This question as to which assets can be seized if one unit is in financial distress would be particularly complicated where the affiliate's borrowing has been from the international debt market, not local banks. Nevertheless, MNCs seem reluctant to let a subsidiary go bankrupt when the enterprise as a whole is financially sound, presumably because of reputation effects. Subsidiary borrowing seems to carry implicit or explicit parent guarantees.

Borrowing in different countries may also not be perfect substitutes for non-tax reasons, contrary to the assumption in the theoretical model. Exchange rate uncertainty may be one reason, although the location of borrowing does not necessarily determine which currency the debt is denominated in. The subsidiary can presumably borrow in dollars and the parent can borrow in foreign currency. In addition, as Desai (1997) suggests, country rules on creditor rights might affect interest costs (even in the same currency), although parent guarantees might offset this consideration. In any case, we wish to focus on tax considerations and, therefore, abstract from currency risks or creditor rights.

In what follows we extend our simple model to investigate how the option of debt financing affects investment incentives for projects at home and abroad. We now allow the parent to invest in a domestic project in periods 1 and 2 with profit function $\mathrm{g}(\mathrm{K})$ where $\mathrm{K}$ denotes domestic capital with $\mathrm{g}^{\prime}>0$ and $\mathrm{g}^{\prime \prime}<0$. For continuity of notation, let $\mathrm{K}_{\mathrm{D}, 0}$ be real capital in the domestic project in period 1 and $\mathrm{K}_{\mathrm{D}, 1}$ equal real capital in period 2. As before, at the end of period zero the parent funds the affiliates with initial equity transfers $\mathrm{K}_{\mathrm{L}, 0}$ and $\mathrm{K}_{\mathrm{H}, 0}$ and transfers $\mathrm{E}_{\mathrm{L}}$ and $\mathrm{E}_{\mathrm{H}}$ at the end of period one. Now, however, these transfers and investment at home may be funded at the parent level through debt. For simplicity, we 
assume that only one-period debt is issued. Let $\mathrm{B}_{0}$ equal debt issued at the end of period 0 and $\mathrm{B}_{1}$ denote debt issued at the end of period 1 .

Assuming that the firm follows optimal debt policy (and therefore does not borrow in the low-tax country) we can abstract from the debt allocation problem. We constrain the amount of debt issued to be less than the capital stock held in the high-tax affiliate and the domestic project: $\mathrm{B}_{0} \leq \mathrm{K}_{\mathrm{D}, 0}+\mathrm{K}_{\mathrm{H}, 0}$. This constraint reflects that as borrowing increases, interest deductions grow and eventually deplete taxable income and the presence of thin capitalization rules in host and home countries. In what follows, we focus on the case in which this constraint is initially not binding. Instead we examine the case in which the debt to asset constraint in the first period binds: $\mathrm{B}_{0} /\left(\mathrm{K}_{\mathrm{D}, 0}+\mathrm{K}_{\mathrm{H}, 0}+\mathrm{K}_{\mathrm{L}, 0}\right)=\mathrm{L}$.

In period 2, the parent may borrow at home against passive assets held in the affiliate subject to similar borrowing constraints: (i) $\left(\mathrm{B}_{1}-\mathrm{P}\right) /\left(\mathrm{K}_{\mathrm{D}, 1}+\mathrm{K}_{\mathrm{H}, 1}+\mathrm{K}_{\mathrm{L}, 1}+\mathrm{R}_{\mathrm{L}}\right) \leq \mathrm{L}$ and (ii) $\mathrm{B}_{1} \leq \mathrm{K}_{\mathrm{H}, 1}+\mathrm{K}_{\mathrm{D}, 1}$. Note, however, that passive assets can now be used as collateral for second period debt. The problem for the parent is to choose debt levels and investment levels in real and financial assets at home and abroad, $\left\{\mathrm{B}_{0}\right.$, $\mathrm{B}_{1}, \mathrm{~K}_{\mathrm{D}, 0}, \mathrm{~K}_{\mathrm{D}, 1}, \mathrm{~K}_{\mathrm{L}, 0}, \mathrm{~K}_{\mathrm{L}, 1}, \mathrm{~K}_{\mathrm{H}, 0}, \mathrm{~K}_{\mathrm{H}, 1}, \mathrm{H}, \mathrm{D}_{\mathrm{L}}, \mathrm{R}_{\mathrm{L}}$, and $\mathrm{P}_{\mathrm{L}}$ \} to maximize the value of equity at home and abroad:

$$
\begin{gathered}
-K_{L, 0}-K_{H, 0}+B_{0}+(1+r)^{-1}\left[\left(g\left(K_{D, 0}\right)-i B_{0}\right)(1-t)+B_{1}-B_{0}\right]-(1+r)^{-2}\left[\left(g\left(K_{D, 1}\right)-i B_{1}\right)(1-t)-B_{1}\right] \\
+(1+r)^{-1}\left[h\left(K_{H, 0}\right)\left(1-t_{H}\right)\left(1-t_{H, d}\right)+H-E_{H}\right]+(1+r)^{-2}\left[h\left(K_{H, 1}\right)\left(1-t_{H}\right)\left(1-t_{H, d}\right)+K_{H, 1}-H\right] \\
+(1+r)^{-1}\left[D_{L}\left(1-t_{L, d}\right)-E_{L}\right] \\
+(1+r)^{-2}\left[f\left(K_{L, 1}+R_{L}\right)\left(1-t_{L}\right)\left(1-t_{L, d}\right)+K_{L, 1}+R_{L}\left(1-t_{d}\right)+\left(1+i\left(1-t_{L}\right)\right) P_{L}\left(1-t_{L, d}\right)+H\left(1-t_{L, d}\right)\right]
\end{gathered}
$$

subject to

(i) $\quad D_{L}=f\left(K_{L, 0}\right)\left(1-t_{L}\right)-R_{L}-P_{L}-H$,

(iii) $\quad \mathrm{B}_{0}<\mathrm{K}_{\mathrm{D}, 0}+\mathrm{K}_{\mathrm{H}, 0}$ 


$$
\frac{\mathrm{B}_{1}-\mathrm{P}}{\mathrm{K}_{\mathrm{D}, 1}+\mathrm{K}_{\mathrm{H}, 1}+\mathrm{K}_{\mathrm{L}, 1}+\mathrm{R}_{\mathrm{L}}} \leq \mathrm{L}
$$

(v) $\quad \mathrm{B}_{1} \leq \mathrm{K}_{\mathrm{H}, 1}+\mathrm{K}_{\mathrm{D}, 1}$

(vi) $\quad \mathrm{H} \leq \mathrm{K}_{\mathrm{H}, 1}$

(vii) $\quad \mathrm{H} \leq \mathrm{f}\left(\mathrm{K}_{\mathrm{L}, 0}\right)\left(1-\mathrm{t}_{\mathrm{L}}\right)$

Note that the maximization problem already takes into account that at the optimum all earnings in the high-tax subsidiary are repatriated at the end of each period $\left(\mathrm{P}_{\mathrm{H}}=0\right.$ and $\left.\mathrm{R}_{\mathrm{H}}=0\right){ }^{25}$

Since we have assumed that the first period worldwide debt to asset constraint is binding $\left[\mathrm{B}_{0} /\left(\mathrm{K}_{\mathrm{D}, 0}+\mathrm{K}_{\mathrm{H}, 0}+\mathrm{K}_{\mathrm{L}, 0}\right)=\mathrm{L}\right]$, the cost of capital abroad and at home are the usual weighted average of the after-tax costs of equity and debt:

$$
\begin{array}{ll}
h^{\prime}\left(K_{H, 0}\right)(1-t)=r(1-L)+i(1-t) L & \text { with respect to } K_{H, 0} \\
g^{\prime}\left(K_{D, 0}\right)(1-t)=r(1-L)+i(1-t) L & \text { with respect to } K_{D, 0}
\end{array}
$$

The solution regions for second period investment depend on which combination of the last four constraints (iv)-(vii) are binding. Since debt is a cheap source of finance, one of the two second period debt constraints will bind [either (iv) or (v)]. ${ }^{26}$ In addition, there will be different solutions depending on the $\mathrm{H}$ constraints [(vi) and (vii)]. We divide our discussion of the solution regions by the debt constraints. In case 1, constraint (iv) binds and the parent can borrow fully against passive assets. In case 2, constraint (v) binds.

Case 1: $\frac{B_{1}-P}{K_{D, 1}+K_{H, 1}+K_{L, 1}+R_{L}}=L$ and $B_{1}<K_{H, 1}+K_{D, 1}$

In case 1 , the parent can fund additional investment by borrowing against passive assets held abroad. Investing in passive assets is as good as investing in (or lending to) the high-tax affiliate since passive assets increase the worldwide borrowing constraint (iv) by an equivalent amount. As a result, the

\footnotetext{
${ }^{25}$ It is easy to show that adding the possibility of debt financing to the model does not change these results established in the previous section.
} 
parent invests in passive assets and the second $H$ constraint does not bind: $H<f\left(K_{L, 0}\right)\left(1-t_{L}\right)$. The $H$ constraint has no effect on the optimal investment conditions in this case because the MNC can always fund additional investment with debt. As a result, there is no bonus from expanding investment in the high-tax subsidiary. The first -order conditions for investment are as follows:

$$
\mathrm{f}^{\prime}\left(\mathrm{K}_{\mathrm{L}, 0}\right)(1-\mathrm{t})=\mathrm{f}^{\prime}\left(\mathrm{K}_{\mathrm{L}, 1}\right)(1-\mathrm{t})=(\mathrm{r}(1-\mathrm{L})+\mathrm{i}(1-\mathrm{t}) \mathrm{L})\left(\frac{2+\mathrm{r}}{2+\mathrm{r} \frac{1-\mathrm{t}_{\mathrm{L}}}{1-\mathrm{t}}}\right)
$$

with respect to $\mathrm{K}_{\mathrm{L}, 0}$ and $\mathrm{K}_{\mathrm{L}, 1}$

$$
\begin{array}{ll}
h^{\prime}\left(K_{H, 1}\right)(1-t)=r(1-L)+i(1-t) L & \text { with respect to } K_{H, 1} \\
g^{\prime}\left(K_{D, 1}\right)(1-t)=r(1-L)+i(1-t) L & \text { with respect to } K_{D, 1}
\end{array}
$$

As in the all equity solutions, all operations are capitalized to steady-state levels immediately, and investment in financial assets increases as taxes abroad decrease (for $\left.t_{L}<t\right)$. In an infinite horizon setting, the steady-state cost of capital in the low tax affiliate is $f^{\prime}\left(K_{L}^{*}\right)=(1-L) r /\left(1-t_{L}\right)+L i(1-t) /\left(1-t_{L}\right)$. This condition reflects that the parent is borrowing in the U.S. and deferring tax on income in the low-tax country.

Case 2: $\frac{B_{1}-P}{K_{D, 1}+K_{H, 1}+K_{L, 1}+R_{L}}<L$ and $B_{1}=K_{H, 1}+K_{D, 1}$

In this case, the triangular strategy is attractive since investing within the worldwide multinational keeps the equity in the company, which can support the normal amount of low cost borrowing. Investing in passive assets is only as good as investing within the multinational if the passive assets increase the worldwide borrowing constraint by an equivalent amount. The parent will use the triangular strategy until it is up against one of the $\mathrm{H}$ constraints. ${ }^{27}$ There are two sub-regions of solutions: (a) $\mathrm{H}<\mathrm{K}_{\mathrm{H}, 1}$ and $\mathrm{H}=$ $\mathrm{f}\left(\mathrm{K}_{\mathrm{L}, 0}\right)\left(1-\mathrm{t}_{\mathrm{L}}\right)$ and $(\mathrm{b}) \mathrm{H}=\mathrm{K}_{\mathrm{H}, 1}$ and $\mathrm{H}<\mathrm{f}\left(\mathrm{K}_{\mathrm{L}, 0}\right)\left(1-\mathrm{t}_{\mathrm{L}}\right)$. In the first, all earnings in the low-tax affiliate are

\footnotetext{
${ }^{26}$ We ignore the knife-edge corner solution in which both bind simultaneously.

${ }^{27}$ We ignore the knife-edge solution in which both bind simultaneously.
} 
reinvested in the high-tax affiliate and passive assets are zero. In the second, the parent is constrained in the use of both alternative repatriation strategies and the underinvestment result obtains. We now examine these cases in detail and show how the cost of capital across locations is related.

Case 2a: $H<K_{H, 1}$ and $H=f\left(K_{L, 0}\right)\left(1-t_{L}\right)$

If the second $\mathrm{H}$ constraint binds, the parent uses only the triangular repatriation strategy. Neither passive assets nor reinvestment is attractive since the high-tax subsidiary has excess equity to repatriate. The first-order conditions for investment are:

$$
\begin{array}{ll}
\mathrm{g}^{\prime}\left(\mathrm{K}_{\mathrm{D}, 1}\right)=\mathrm{i} & \text { with respect to } \mathrm{K}_{\mathrm{D}, 1} \\
\mathrm{~h}^{\prime}\left(\mathrm{K}_{\mathrm{H}, 1}\right)=\mathrm{i} & \text { with respect to } \mathrm{K}_{\mathrm{H}, 1} \\
\mathrm{f}^{\prime}\left(\mathrm{K}_{\mathrm{L}, 0}\right)(1-\mathrm{t})=\mathrm{f}^{\prime}\left(\mathrm{K}_{\mathrm{L}, 1}\right)(1-\mathrm{t})=\frac{(\mathrm{r}(1-\mathrm{L})+\mathrm{i}(1-\mathrm{t}) \mathrm{L})(2+\mathrm{r})+\mathrm{L}(\mathrm{r}-\mathrm{i}(1-\mathrm{t}))}{2+\mathrm{r} \frac{1-\mathrm{t}_{\mathrm{L}}}{1-\mathrm{t}}} \quad \text { with respect to } \mathrm{K}_{\mathrm{L}, 0} \text { and } \mathrm{K}_{\mathrm{L}, 1}
\end{array}
$$

The cost of capital is lower at home and in the high-tax subsidiary than in case 1 (and in period 1) since an additional dollar of investment can now be funded by low-cost borrowing (recall that in this case $\mathrm{B}_{1}=$ $\mathrm{K}_{\mathrm{H}, 1}+\mathrm{K}_{\mathrm{D}, 1}$ ). At the same time, the marginal cost of investing in the low-tax affiliate increases, relative to case 1, by $\mathrm{L}(\mathrm{r}-\mathrm{i}(1-\mathrm{t}))$ since this investment can not support additional low cost borrowing at home.

Case $2 \boldsymbol{b}: H=K_{H, 1}$ and $H<f\left(K_{L, 0}\right)\left(1-t_{L}\right)$

In this case, the high-tax subsidiary is constrained in its use of $\mathrm{H}$ and, because it is unable to borrow against them, passive assets do not generate a favorable return relative to reinvestment. As a result, we are back to the Hartman-Sinn world in which the parent underinvests in the low-tax subsidiary. The investment rules are:

$$
\mathrm{g}^{\prime}\left(\mathrm{K}_{\mathrm{D}, 1}\right)=\mathrm{i}
$$

with respect to $\mathrm{K}_{\mathrm{D}, 1}$ 


$$
\mathrm{h}^{\prime}\left(\mathrm{K}_{\mathrm{H}, 1}\right)=\mathrm{i}-\frac{\mathrm{r}}{1-\mathrm{t}_{\mathrm{L}}}
$$

with respect to $\mathrm{K}_{\mathrm{H}, 1}$

$$
\begin{array}{ll}
f^{\prime}\left(K_{L, 0}\right)(1-t)=1+r(1-L)+i(1-t) L-\left(\frac{1+r\left(1-t_{L, d}\right)}{1+r}\right) & \text { with respect to } K_{L, 0} \\
f^{\prime}\left(K_{L, 1}+R_{L}\right)\left(1-t_{L}\right)=r & \text { with respect to } R_{L}
\end{array}
$$

Equation (19) shows that investment at home is funded fully with debt. Equation (20) shows that the cost of capital in the high-tax subsidiary in period two is even less than the cost of borrowing since any additional equity can support the triangular strategy (recall that $\mathrm{H}=\mathrm{K}_{\mathrm{H}, 1}$ in this region). As in the allequity case considered previously, equity is trapped in both the high-tax and the low-tax subsidiary. As a result, the corporate rate in the low-tax country plays a role in determining optimal equity transfers in all affiliates. Finally note that the cost of capital in the low-tax subsidiary in period two reflects that the parent is constrained its use of debt and must use expensive equity to finance investment in the low-tax jurisdiction.

\subsection{Incentives for excess credit parents: The allocation of debt}

Introducing a worldwide debt to asset constraint may also affect the financing and investment decisions of multinationals in excess credit positions. ${ }^{28}$ To see this we analyze a simple model in which the parent can borrow both at home and on the local market to fund investment projects. ${ }^{29}$ However, as before, we assume that the multinational's worldwide debt to asset ratio may not exceed $\mathrm{L}$ and that the affiliate (parent) can not borrow more than the capital stock abroad (at home). We also continue to assume that $\mathrm{i}\left(1-\mathrm{t}_{\mathrm{L}}\right)>\mathrm{r}$.

\footnotetext{
${ }^{28}$ Altshuler and Mintz (1995) solve a similar debt allocation problem in the presence of the recent U.S. rules requiring that parents allocate a portion of interest expense to foreign income. These allocations reduce allowable foreign tax credits and reinforce the incentive for shifting (unrelated) debt to high-tax foreign affiliates that is the subject of this section. We plan to address the interest allocation issue in a separate paper.

${ }^{29}$ Recall that if the parent were in excess limitation it would be indifferent between borrowing at home or in the high-tax country and would place no debt in the low-tax country.
} 
When the parent is an excess credit foreign tax credit position there is no advantage to deferral. Consequently, all alternatives to dividend repatriation are equivalent and are dominated by dividends. The parent optimally repatriates all profits at the end of each year. As a result, the two period problem reduces to single period problem which is repeated in the second year (or indefinitely in an infinite horizon problem).

The firm chooses $B_{D}, B_{L}, B_{H}, K_{D}, K_{L}$, and $K_{H}$ to solve the following problem subject to the constraints described above:

$$
\begin{gathered}
\max \left(g\left(K_{D}\right)-i B_{D}\right)(1-t)+\left(f\left(K_{L}\right)-i B_{L}\right)\left(1-t_{L}\right)+\left(h\left(K_{H}\right)-i B_{H}\right)\left(1-t_{H}\right)-r\left(K_{L}+K_{H}+K_{D}-B_{L}-B_{H}-B_{D}\right) \\
\text { subject to } \frac{B_{L}+B_{H}+B_{D}}{K_{L}+K_{H}+K_{D}} \leq L \\
B_{L} \leq K_{L}, B_{H} \leq K_{H} \text {, and } B_{D} \leq K_{D}
\end{gathered}
$$

where $\mathrm{B}_{\mathrm{D}}$ represents debt on the domestic company's books, $\mathrm{B}_{\mathrm{L}}$ represents debt on the low-tax CFC's books, and $\mathrm{B}_{\mathrm{H}}$ represents debt on the high-tax CFC's books. Faced with this problem, the firm will allocate as much debt abroad in the high-tax country as possible $\left(\mathrm{B}_{\mathrm{H}}=\mathrm{K}_{\mathrm{H}}\right)$ and will not borrow in the low-tax country $\left(\mathrm{B}_{\mathrm{L}}=0\right) .{ }^{30}$ Investment rules at home and abroad will depend on whether the worldwide debt to asset constraint is binding or the domestic debt constraint $\left(\mathrm{B}_{\mathrm{D}} \leq \mathrm{K}_{\mathrm{D}}\right)$ binds. ${ }^{31}$

Case 1: $B_{D}<K_{D}$ and $\frac{B_{L}+B_{H}+B_{D}}{K_{L}+K_{H}+K_{D}}=L$

The first-order conditions with respect to $\mathrm{K}_{\mathrm{H}}, \mathrm{K}_{\mathrm{D}}$, and $\mathrm{K}_{\mathrm{L}}$ are:

$$
h^{\prime}\left(K_{H}\right)\left(1-t_{H}\right)=r(1-L)+i\left(1-t_{H}\right) L-i(1-L)\left(t_{H}-t\right)
$$

\footnotetext{
${ }^{30} \mathrm{We}$ do not discuss in the text the case in which the real capital held in the high-tax CFC is substantial enough to support investment everywhere in the MNC. In this case, $\mathrm{B}_{\mathrm{H}}<\mathrm{K}_{\mathrm{H}}$ and $\left(\mathrm{B}_{\mathrm{L}}+\mathrm{B}_{\mathrm{H}}+\mathrm{B}_{\mathrm{D}}\right) /\left(\mathrm{K}_{\mathrm{L}}+\mathrm{K}_{\mathrm{H}}+\mathrm{K}_{\mathrm{D}}\right)=\mathrm{L}$. The first-order conditions for investment in the high-tax CFC, low-tax CFC, and at home are, respectively: $h^{\prime}\left(K_{H}\right)\left(1-t_{H}\right)$ $=r(1-\mathrm{L})+\mathrm{i}\left(1-\mathrm{t}_{\mathrm{H}}\right) \mathrm{L}, \mathrm{f}^{\prime}\left(\mathrm{K}_{\mathrm{L}}\right)\left(1-\mathrm{t}_{\mathrm{L}}\right)=\mathrm{r}(1-\mathrm{L})+\mathrm{i}\left(1-\mathrm{t}_{\mathrm{H}}\right) \mathrm{L}$, and $\mathrm{g}^{\prime}\left(\mathrm{K}_{\mathrm{D}}\right)(1-\mathrm{t})=\mathrm{r}(1-\mathrm{L})+\mathrm{i}\left(1-\mathrm{t}_{\mathrm{H}}\right) \mathrm{L}$.

${ }^{31}$ In the case in which both bind simultaneously $\mathrm{K}_{\mathrm{L}}=\left(\mathrm{K}_{\mathrm{H}}+\mathrm{K}_{\mathrm{D}}\right)(1-\mathrm{L}) / \mathrm{L}$. The first order conditions for investment reflect this relationship between capital stocks: $g^{\prime}\left(K_{D}\right)(1-t)=(r(1-L)+i(1-t) L)(1-L) / L, h^{\prime}\left(K_{H}\right)\left(1-t_{H}\right)=(r(1-L)+i(1-$ $\left.\left.t_{H}\right) L\right)(1-L) / L$, and $f^{\prime}\left(K_{L}\right)\left(1-t_{L}\right)=r$.
} 


$$
g^{\prime}\left(K_{D}\right)(1-t)=r(1-L)+i(1-t) L
$$

$$
f^{\prime}\left(K_{L}\right)\left(1-t_{L}\right)=r(1-L)+i(1-t) L=r(1-L)+i\left(1-t_{L}\right) L-i L\left(t-t_{L}\right)
$$

Equation (23) shows that the cost of capital in the high-tax subsidiary is lower than the standard one since extra investment in real assets increases the parent's worldwide debt capacity. The affiliate could always borrow $\mathrm{L}$ and deduct interest costs at the tax rate $\mathrm{t}_{\mathrm{H}}$ even without any debt reallocation. This is indicated by the second term in equation (23). But with debt reallocation, the affiliate borrows 1-L in addition, which would ordinarily be financed with equity. Its cost of capital is therefore reduced by 1-L times the increased interest deductions from the reallocation. The cost of capital is lower than the standard one in the low-tax affiliate for similar reasons. Debt reallocation allows the affiliate to borrow L in addition at a lower cost and save iL $\left(t-t_{L}\right)$. It is also interesting to note that the cost of capital in the low-tax affiliate is the same as in the (infinite horizon) excess limitation case in which the parent funds additional investment by borrowing against passive assets.

Case 2: $B_{D}=K_{D}$ and $\frac{B_{L}+B_{H}+B_{D}}{K_{L}+K_{H}+K_{D}}<L$

The first-order conditions with respect to $\mathrm{K}_{\mathrm{H}}, \mathrm{K}_{\mathrm{D}}$, and $\mathrm{K}_{\mathrm{L}}$ are:

$$
\begin{aligned}
& h^{\prime}\left(K_{H}\right)=i \\
& g^{\prime}\left(K_{D}\right)=i \\
& f^{\prime}\left(K_{L}\right)=\frac{r}{1-t_{L}}
\end{aligned}
$$

The cost of capital is decreased both at home and abroad relative to the standard weighted average cost of capital since marginal investment can be fully funded with debt. The cost of capital in the low-tax country reflects that the parent must fund marginal investment in this CFC with equity. 


\section{Empirical Results}

Our theoretical analysis suggests the various strategies that companies can use to achieve the

equivalent of repatriation, i.e., getting cash to the parent, without incurring the tax costs of repatriation:

(1) The foreign subsidiary can invest in passive assets, which the parent can then borrow against. A closely related strategy would be to pay off local debt so that the parent can borrow more.

(2) The low-tax subsidiary can invest in other related foreign affiliates. If the latter are high-tax, they can repatriate their own earnings, paying little or no repatriation taxes because of available credits, while using the infusion from their low-tax siblings for their own investment requirements.

(3) Similarly, the low-tax subsidiary can lend its earnings to a related foreign affiliate.

(4) The multinational can lighten the tax cost of repatriations from a low-tax subsidiary by initially injecting capital to it through a high-tax subsidiary which becomes its direct upper-tier owner. The high-tax direct owner should be in an exemption or territorial country so that any incoming dividend from its lower-tier affiliate does not attract any further local tax. When the low-tax subsidiary pays a dividend through the upper tier high-tax owner, the dividends that come back to the United States will carry credits that are a blend of the tax rates paid by the high and low-tax siblings.

We use CFC by CFC balance sheet and payment data to test the empirical significance of these possible strategies. Do subsidiaries in low-tax countries with high potential repatriation taxes invest in more passive assets and do they lend to or invest in related foreign affiliates? Do they pay off more third party debt so that the parent can borrow more? Do the low-tax subsidiaries pay a greater proportion of their dividends to other foreign affiliates, rather than directly to the parent, so that they can get higher, blended credits?

We also explore the empirical importance of tax considerations in explaining CFC debt holdings. The analysis in section 2.4 suggests that CFC debt should increase with local statutory tax rates. Although previous work has pointed out the advantages of locating debt in high-tax countries, the balance sheet data available in the Treasury files is the only data set we are aware of that provides information on the location of CFC debt for a large set of multinationals. The debt data can also be used to examine strategies closely related to the repatriation tax avoidance scheme outlined above. As we have noted, a CFC with high potential repatriation taxes would pay off any local debt before investing in passive assets. 
Before proceeding to explain our balance sheet and payment regressions, we should mention a feature of the real world data that may not have been fully reflected in the theoretical model. (It would have added too many complications.) As mentioned in section 2.1, the theoretical model assumed that the corporate statutory tax rate, the average effective tax rate, and the marginal effective tax rate were all the same. In fact, effective tax rates are frequently lower than the simple statutory tax rate because of incentives such as investment credits. We will, in some specifications use both as explanatory variables because of their potentially differing impact on behavior. For example, a CFC may be in a country with a low effective tax rate, because of generous incentives, but a high statutory tax rate. The high statutory tax rate may induce a high amount of local debt. At the same time, the CFC will face a high-tax on dividend repatriations, if its parent is in excess limit, because of the low effective tax rate. It will, therefore, have a tax incentive to engage in some of the strategies outlined above.

\subsection{The Data}

The 1996 corporate tax files compiled by the Statistics of Income (SOI) Division of the Internal Revenue Service form the basis for our study of affiliate balance sheets. This data set is constructed from information from three sets of forms filed by U.S. parent corporations: the basic corporate tax form (Form 1120), the form used to claim a foreign tax credit (Form 1118), and Form 5471 which reports on the activities of each CFC of a U.S. parent.

Most of our analysis is confined to the largest 7,500 CFCs in terms of assets because many of the critical variables are only edited by SOI for these companies. Because of various exclusions, such as parents with part-year returns and other data inconsistencies, we are left with about 6,000 CFCs, approximately 4,000 of which are non-financial.

Several types of tax variables appear in the empirical work. Country statutory tax rates and withholding taxes on dividends and interest were obtained from the Price Waterhouse Guides. ${ }^{32}$ The

\footnotetext{
${ }^{32}$ The U.S. treaty rates, if any, for the withholding taxes were used.
} 
statutory tax rate used in the analysis, unless otherwise specified, is the rate on manufacturing income. ${ }^{33}$ In some countries, such as Ireland and Canada, manufacturing receives a special low-tax rate, which may not apply to interest and other investment income. As explained further below, we also calculate country average effective tax rates using information from the Form 5471. These effective tax rates are used to construct the CFC's long-run repatriation taxes.

\subsection{Balance Sheet Information and the Choice of Variables}

Table 1 gives the average asset and liability shares of the CFCs in the sample. The list of assets in Table 1 provide the categories available in the Treasury data for testing the existence of the alternatives to direct repatriation that are the subject of this paper. Identifying "passive" assets, by which we mean liquid, marketable financial instruments issued by unrelated parties, is the most difficult. For the sake of being conservative, we choose "cash" plus "other current assets." The other potential candidates may have important features distinct from "true" passive assets. For example, "accounts receivable" may well include trade loans to related parties that are used to shift income to more favorable locations.

Identifying the "triangular" investment in related parties strategy is more straightforward. We use "Investment in Affiliates" and "Loans to Affiliates" as distinct, separate components of this strategy because they may be influenced by different tax considerations. The choice between these two alternatives may depend on withholding taxes on interest versus dividends and also on the local statutory tax rate. The latter may be important in the choice because dividends in an equity investment can be deferred indefinitely while interest income presumably continues to accrue.

The "multiple tiers" strategy in which a low-tax subsidiary is owned by a higher-tier subsidiary in order to get a higher blended rate of tax credits on distributions will be identified from the composition of dividends paid by the CFC. The analysis of the allocation of debt among subsidiaries, which as we have

\footnotetext{
${ }^{33}$ In countries with exemption systems, foreign dividend income is exempt from tax. CFCs organized in these jurisdictions could, therefore, receive income from lower-tier affiliates free from local tax irrespective of the statutory corporate tax rate that applies to other income.
} 
noted is related to the dividend-tax avoidance strategies, will be based on the liability categories at the bottom of Table 1.

Table 1 shows that financial assets are clearly significant, indeed they exceed "real" assets, e.g., plant, equipment and inventories, even in non-financial companies. Passive assets (using our definition of "cash" plus "other current assets") make up almost thirteen percent of total assets in non-financial CFCs and about fifteen percent of the total assets of all CFCs. Loans to affiliates and investment in affiliates are also quantitatively important, accounting for almost twenty-two percent of total CFC assets when financial CFCs are included, and more than thirteen percent when financial CFCs are excluded.

Before proceeding with the regression analysis, we review the independent variables used in the analysis. Both tax and non-tax variables are included. The repatriation tax on dividends played a critical role in the theoretical model. But we do not use the company's actual repatriation tax (on the margin) which depends on the foreign tax credit position of the parent. One reason is that the theoretical model has focused primarily on the strategies that excess limit companies use to avoid the repatriation tax. A CFC with an excess credit parent that faces a high dividend repatriation tax (because of a high local withholding tax) might use other strategies such as investing in the parent, which would be the simplest way to get cash back home. ${ }^{34}$ It is, therefore, necessary to distinguish between these two potential sources of a high repatriation tax.

Another reason for not using the standard actual repatriation tax is that the parent may be uncertain about its excess credit position, even in the current year because of audits. If the current position is very close to the excess credit threshold, it may not be a useful guide to the parent's expectations and its resulting strategies.

We, therefore, start out by introducing two separate dividend repatriation taxes into the regressions, one for the repatriation tax that would apply if the parent were in excess limit, and the other

\footnotetext{
${ }^{34}$ This investment in U.S. property would trigger a deemed dividend distribution under the U.S. rules, but this would be shielded by the parent's excess credits.
} 
applying to an excess credit parent. Both taxes can be relevant from the company's point of view because each one may possibly apply.

We then, in another set of regressions, introduce information on the parent's actual repatriated income and credits without being restricted only to the simple all-or-nothing excess credit threshold. The indicator is the ratio of total foreign taxes paid to total net foreign source income. The greater this rate, the less likely the company is to be in excess limit now or in the future. ${ }^{35}$ The overall foreign tax rate on foreign income is then interacted with the excess limit repatriation tax and added as another explanatory variable. The coefficient of this interaction term is expected to be negative in the financial asset equations because, as the variable increases, holding the excess limit repatriation tax constant, the parent is less likely to be in excess limit in the long run. It is less likely to be engaging in the strategies that are the major subject of this paper. (In the debt allocation regressions, which are based on the analysis of debt allocation in the excess credit case above, we interact the overall foreign tax rate with the local statutory tax rate, which determines the tax saving from interest deductions for excess credit companies.)

As mentioned in section 2, the dividend gross up required to calculate the repatriation tax for firms in excess limit is determined by the CFC's effective tax rate (ETR). In particular, in 1996 when the U.S. corporate rate was 35 percent, the excess limit tax price on dividends was the tax on the grossed up dividend after the credit, or (.35-ETR)/(1-ETR). Instead of using CFC specific effective tax rates, we use the country average effective tax rate in manufacturing to calculate the excess limit tax price. This allows us to focus on responses to permanent as opposed to transitory tax rate differences.

Among the few non-tax explanatory variables included in our regressions are two age dummies based on the foreign subsidiary's date of incorporation. One is for companies incorporated within the last five years and the other is for those that were incorporated between five and fifteen years ago. CFC financial behavior may be expected to change as it matures and accumulates profits.

\footnotetext{
${ }^{35}$ Using 1984 and 1992 data, Grubert (2000) finds that there is significant persistence in this rate.
} 


\subsection{Regression Results}

Table 2 presents the financial asset regressions that attempt to see if companies follow some of the repatriation tax avoidance strategies suggest by the theoretical model. All CFCs, including those in finance, are included. The main issue in these regressions is the influence of the dividend repatriation tax if the parent company is in excess limit. The theoretical model has, as in the Hartman-Sinn literature, emphasized the case of the low-tax subsidiary with an excess limit parent. ${ }^{36}$ If the parent has excess credits and the host country withholding tax on dividends is the tax barrier to repatriations, other strategies such as lending money to the parent may dominate.

In the first set of regressions in Table 2, for each of the three financial asset categories, the only tax variables are the two dividend tax prices. Consistent with our theoretical analysis, the coefficients of the excess limit dividend repatriation tax are positive and highly significant. CFCs appear to invest in these alternatives to repatriation when they face a high potential dividend repatriation tax.

The coefficients of the dividend withholding taxes, the tax price if the parent is in excess credit, are negative and significant in one case, for investment in affiliates. But the strategies described above are directed to the more common excess limit scenario. As noted earlier, the CFC with an excess credit parent has other ways of avoiding a host country withholding tax. It can lend money to the parent, which would trigger an income inclusion by the parent but this would be of no consequence if the parent has excess credits. It could also increase payments for royalties and other services. Finally, it is not surprising that a multinational would avoid accumulating financial assets in a country with high withholding taxes on dividends because it runs the risk of paying taxes that cannot be credited.

Since only 42 percent of CFCs made loans to affiliates and 72 percent invested in affiliates we also ran Tobit regressions. The results were generally quite similar, although as usual the Tobit coefficients were much larger in absolute value. The elasticities are comparable once the probability of being above the threshold is factored into the calculation. To save on space, we do not discuss the Tobit

\footnotetext{
${ }^{36}$ From 1992 to 1996, an average of about a third of all repatriated manufacturing income was received by parents in excess credit positions.
} 
results except in cases in which there was a significant change in the magnitude or economic significance of a coefficient. ${ }^{37}$

In the second set of regressions in Table 2, the host country statutory tax rate is added as an independent variable. The coefficients of the excess limit dividend repatriation tax remain positive and highly significant for investment in subsidiaries and loans to affiliates. But the coefficient in the passive assets equation becomes negative, which may not be surprising because of the very high (negative) correlation between the statutory tax rate and the dividend tax rate, which depends on the effective tax rate.

The motivation for adding the statutory tax rate as an explanatory variable is that it could be affecting behavior on other margins and biasing the estimated effect of the potential repatriation tax. For example, a low statutory tax rate can attract shifted income, which is then invested in passive assets. ${ }^{38}$ Financial assets would presumably be one way in which the retained earnings can be invested. The income shifted to low-tax countries is unlikely to be completely invested in local real assets.

The sensitivity of the passive asset results to the inclusion of the statutory tax rate may be attributable to several other factors. One is that the asset categories available in the balance sheet data make it difficult to identify passive assets very precisely. Also, the theoretical model assumed that borrowing against passive assets is costless. Borrowing-lending spreads may, in fact, be large enough to make triangular strategies more dominant. Investing in or lending to a related foreign affiliate may be clearly preferable as long as, somewhere in the worldwide multinational, a subsidiary would otherwise be obtaining funds from outside sources or from the U.S. parent. Finally, as we noted at the beginning, there is a disadvantage to passive assets since income included in the parent's tax return is in the passive basket and therefore not in a position to absorb spillover credits from active income.

\footnotetext{
${ }^{37}$ The Tobit results are available upon request from the authors.

${ }^{38}$ But note that, in the Hartman-Sinn model, any income is repatriated if it is not invested in the CFCs own real assets. An excess limit multinational would, however, only shift income to a low-tax location if the income can retained there.
} 
Note that in the equation for investments in other affiliates, the coefficient for the local statutory tax rate is significant and positive. Choosing an equity investment in another affiliate has the advantage of avoiding the local statutory tax rate on any income because dividends can be deferred indefinitely by the lower-tier affiliate. (Indeed the lower-tier affiliate can avoid the upper-tier country tax altogether by lending money directly to the parent.)

The third set of regressions in Table 2 introduce the indicator of the parent's long run credit position described earlier, the overall foreign tax rate on repatriated income, which is interacted with the excess limit repatriation tax. The interaction term is expected to have a negative coefficient because a larger foreign tax rate makes it less likely than the excess limit strategies apply. In fact, that turns out to be the case, and furthermore the interaction term is statistically significant for passive assets and loans to affiliates. At the same time, the magnitude of the basic excess limit repatriation tax coefficient rises compared to the comparable first set of regressions. This evidence suggests that CFCs in low effective tax countries (and thus with high potential excess limit repatriation taxes) that are controlled by a parent that is far in excess limit are more likely to be following the strategies hypothesized in this paper.

The last regression in Table 2 has accumulated retained earnings as the dependent variable with the age dummies, the two dividend tax prices and current earnings as explanatory variables. The age and current earnings variables have the expected sign and are highly significant. In addition, the dividend repatriation taxes have positive, highly significant coefficients. This gives some support to our view that a high repatriation tax increases retained earnings, in contrast to the Hartman-Sinn world, and some of these retentions may be invested in financial assets.

Table 3 examines the multiple tier strategy, in which a low-tax affiliate is owned by an upper-tier high-tax affiliate. Then any repatriations of low-tax income, which go through the high-tax subsidiary, can receive greater foreign tax credits from the blend of the high and low tax rates. ${ }^{39}$ The dependent variable is the ratio of dividends paid to another $\mathrm{CFC}$ to total dividends paid. We expect that CFCs with

\footnotetext{
${ }^{39}$ The dividend received by the upper tier CFC will be taxed currently by the United States unless the blended foreign tax rate is greater than 90 percent of the U.S. rate.
} 
higher excess limit repatriation taxes on direct dividends to the United States will make greater use of dividends paid through another CFC.

As mentioned above, another important requirement of the strategy is that the upper tier high-tax CFC be in a dividend exemption (territorial) country where any incoming dividend would not attract any further tax. This would, however, make any dividend withholding tax charged by the low-tier low-tax country costly because it would not be creditable. High dividend withholding taxes on dividends would, therefore, strongly discourage this strategy. The regressions in Table 3, therefore, have the excess limit tax price of dividends direct to the United States and the dividend withholding tax rate as independent variables. In addition, besides the CFC age dummies, we include the CFC's subpart F income in relation to total assets. A CFC's subpart F income includes items such as interest and dividends and is currently included in the parent's U.S. taxable income. The parent does not, therefore, have to scheme to avoid a repatriation tax on this income because it has already been paid.

Table 3 confirms the significance of this credit-blending strategy. The coefficient of the excess limit tax price on direct dividends is positive and significant. The coefficient for the local withholding tax on dividends is negative, as expected, and highly significant. The coefficient of the subpart $\mathrm{F}$ variable is negative, as expected, but is only of borderline statistical significance.

Table 4 reports on the relationship between CFC debt and the tax variables. In addition to regressions for total debt, we also present separate regressions for related party debt and arms' length borrowing from third parties. In the first set of regressions in Table 4, the independent variables are simply the age dummies, the statutory tax rate and the withholding tax on interest. The regressions show the expected large impact of a higher local statutory tax rate in increasing local debt. ${ }^{40}$ The withholding

\footnotetext{
${ }^{40}$ In some of the debt regressions, we added the interaction of the statutory rate with the overall foreign tax rate on repatriated income, the indicator of the parent's excess credit position used in Table 2. Parents in excess credit have an added incentive to put debt in high tax countries because it reduces foreign taxes that are not useful as credits. In addition, shifting debt from the United States reduces the domestic interest expense that has to be allocated to foreign income. (If the parent is in excess limit, a shift of debt from the United States to a high-tax country will reduce useable foreign tax credits by the amount of the tax saving abroad.) The interaction variable, however, has no statistical significance. When the overall foreign tax rate by itself is added as well, it has a positive coefficient while the interaction term is negative, both significant at the 5 percent level. This pattern may suggest that an excess credit parent has an incentive to lower any foreign tax, even in a low-tax country. Debt shifted from the United
} 
tax rate on interest turns out to have a significant negative effect on the amount of related party debt, where it would be relevant because it applies to cross-border payments.

The second set of regressions in Table 4 add the dividend repatriation tax variables, accumulated retained earnings and the interaction of the excess limit repatriation tax with accumulated earnings. The purpose is to see whether CFCs use their retained earnings to pay off local debt if they face a high dividend repatriation tax. We see that the coefficient of the interaction of the retained earnings and the dividend tax variables is negative in all cases and significant for both total debt and unrelated, arms' length debt. As we have noted, paying off local debt is another version of the passive asset strategy because a CFC with a high repatriation tax will pay off any debt first before accumulating passive assets; it would save the borrowing-lending spread as well as any current U.S. tax on passive interest received. The results seem to confirm that multinationals follow this strategy and provides stronger evidence for the "passive assets" strategy than the direct evidence on actual passive asset holdings.

One potential problem with our empirical results is that they may reflect systematic differences among parents rather than responses to local tax considerations. Some MNCs may, in general, be more highly leveraged or hold more passive assets than others. To test this possibility, we introduced parent fixed effects into the regressions in Tables 2 and 4. We found that the results were generally unaffected by the addition of fixed effects. ${ }^{41}$ Indeed, the size of the statutory tax rate coefficient in the debt regressions in Table 4 increases and remains highly significant. In the case of the financial asset regressions in Table 2, the excess limit repatriation tax remains statistically significant in all cases where it had been in the comparable non-fixed-effects regression. The coefficient is notably smaller in the passive assets and affiliate loans regressions while remaining highly statistically significant. ${ }^{42}$

\footnotetext{
States to a low-tax country will also yield the lower interest allocation benefit. On the other hand, the analysis of the excess limit case indicated that MNCs would only borrow in high-tax countries while they defer repatriations in low-tax countries. Thus, an excess credit company may have more debt in low-tax locations than excess limit companies who want to obtain the full advantage of deferral.

${ }^{41}$ The fixed effects regression results are not displayed to conserve on space but are available from the authors upon request.

${ }^{42}$ This reduction may not be surprising because it may reflect the fact that parents that tend to invest in low-tax
} 


\section{Conclusions}

Several investment-repatriation strategies are added to the standard model of a parent and its affiliate in which the affiliate is limited to two alternatives: repatriating direct dividends to the parent or investing in its own real operations. In our model, the low-tax subsidiary can invest in passive assets which the parent can borrow against, making any direct flow to the parent unnecessary. The low-tax subsidiary can also use its earnings to invest in a related high-tax affiliate which becomes the vehicle for tax-free repatriations. Alternatively, the low-tax affiliate can be capitalized by equity injections through an upper-tier sibling. This lowers the tax on repatriations by the low-tax subsidiary because the foreign tax credits at home are based on a blend of the two tax rates.

The availability of these strategies can have an effect on real investment in the low-tax subsidiary and throughout the worldwide corporation. If low-tax subsidiaries can achieve the equivalent of tax-free repatriations, they do not have to "underinvest" initially to obtain the benefits of deferral. If retained lightly-taxed earnings are "trapped" because of the repatriation tax, they are trapped in all foreign subsidiaries as a group, including high-tax ones, because they are able to use the funds.

Firm level balance sheet and payment data for U.S. multinational corporations and their affiliates show the importance of these alternative strategies. The evidence is generally consistent with the theory, particularly the "triangular" strategies using related affiliates. Controlled foreign corporations that face high repatriation taxes make greater investments in related affiliates and send a greater share of their dividends to other foreign affiliates. In addition, they also pay off more local debt as they accumulate retained earnings which is another version of the "passive assets" strategy considered in our analytical model.

locations tend to follow the strategies that we suggest. These MNCs are the ones we would expect to be the most aggressive tax planners and are also the ones that are more likely to be in permanent excess limit positions. 


\section{References}

Altshuler, Rosanne and Paolo Fulghieri. 1994. "Dynamic Effects of Foreign Tax Credits on Multinational Corporations," National Tax Journal, June 1994, 349-61.

Altshuler, Rosanne and Jack Mintz. 1995. "U.S. Interest Allocation Rules: Effects and Policy," International Taxation and Public Finance, volume 2, number 1, 7-35.

Altshuler, Rosanne and T. Scott Newlon. 1993. "The Effects of U.S. Tax Policy on the Income Repatriation Patterns of U.S. Multinational Corporations," in A. Giovannini, G. Hubbard, and J. Slemrod, editors, Studies in International Taxation, University of Chicago Press.

Altshuler, Rosanne, T. Scott Newlon and William C. Randolph. 1995. "Do Repatriation Taxes Matter? Evidence from the Tax Returns of U.S. Multinationals," in M. Feldstein, J. Hines, and G. Hubbard, editors, The Effects of International Taxation on Multinational Corporations. Chicago: University of Chicago Press, 253-272.

Desai, Mihir. 1997. "A Multinational Perspective on Capital Structure Choice and Internal Capital Markets.” Mimeograph, Harvard Business School.

Froot, Kenneth and James R. Hines. 1995. "Interest Allocation, Financing Patterns, and the Operations of U.S. Multinationals, " in M. Feldstein, J. Hines, and G. Hubbard, editors, The Effects of Taxation on Multinational Corporations. Chicago: University of Chicago Press, 277-312.

Grubert, Harry. 2000. "Tax Planning by Companies and Tax Competition by Governments: Is There Evidence of Changes in Behavior?" forthcoming in James R. Hines, Jr., editor, International Taxation and Multinational Activity, University of Chicago Press.

Grubert, Harry. 1998. "Taxes and the Division of Foreign Operating Income among Royalties, Interest, Dividends and Retained Earnings," Journal of Public Economics 68 No. 2, 269-90.

Grubert, Harry and John Mutti. 1999. "Dividend Exemption versus the Current System for Taxing Foreign Business Income." Mimeograph.

Hartman, David. 1985. "Tax Policy and Foreign Direct Investment," Journal of Public Economics, volume $26,107-21$.

Hines, James R. and R. Glenn Hubbard. 1990. "Coming Home to America: Dividend Repatriations by U.S. Multinationals," in A. Razin and J. Slemrod, editors, Taxation in the Global Economy. Chicago: University of Chicago Press, 161-200.

Hines, James R. 1994. "Credit and Deferral as International Investment Incentives," Journal of Public Economics, volume 55, 323-347.

Hines, James R. and Eric Rice. 1994. "Fiscal Paradise: Foreign Tax Havens and American Business," Quarterly Journal of Economics, volume 109, 149-182.

Horst, Thomas. 1977. "American Taxation of Multinational Firms," American Economic Review, volume 67, 376-389. 
Leechor, Chad and Jack Mintz. 1993. "On the Taxation of Multinational Corporate Investment When the Deferral Method is Used by the Capital Exporting Country," Journal of Public Economics, volume 51, 75-96.

Price Waterhouse. 1992. Corporate Taxes: A Worldwide Summary, New York.

Newlon, T. Scott. 1987. "Tax policy and the multinational firm's financial policy and investment decisions." Ph.D. dissertation, Princeton University.

Sinn, Hans Werner. 1984. "Die Bedeutung des Accelerated Cost Recovery System fur den internationalen Kapitalverkehr," Kyklos, volume 37, 542-576.

Sinn, Hans Werner. 1993. "Taxation and the Birth of Foreign Subsidiaries," in Trade, Welfare, and Economic Policies: Essays in Honor of Murray C. Kemp, edited by H. Herberg and N.V. Long. Ann Arbor: University of Michigan Press, 325-352.

Stiglitz, Joseph and Andrew Weiss. 1981. "Credit Rationing in Markets with Imperfect Information." American Economic Review, volume 71, 393-410.

Weichenrieder, A. J. 1996. "Anti Tax-avoidance Provisions and the Size of Foreign Direct Investment," International Tax and Public Finance, volume 3, 67-81. 
Table 1

\section{Asset and Liability Shares of CFCs in 1996}

\begin{tabular}{|c|c|c|}
\hline Ratio of items to total CFC assets: & Non-financial CFCs & All CFCs \\
\hline \multicolumn{3}{|l|}{ Assets } \\
\hline Cash & .056 & .059 \\
\hline Accounts Receivable & .249 & .221 \\
\hline Other Current Assets & .070 & .094 \\
\hline Loans to Affiliates & .064 & .086 \\
\hline Investment in Affiliates & .073 & .131 \\
\hline Other Investments & .026 & .052 \\
\hline Net Plant and Equipment & .241 & .176 \\
\hline Land and Depletable Assets & .017 & .013 \\
\hline Inventories & .126 & .091 \\
\hline Other Assets & .078 & .077 \\
\hline \multicolumn{3}{|l|}{ Liabilities } \\
\hline Accounts Payable & .167 & .140 \\
\hline Other Current Liabilities & .166 & .160 \\
\hline Loans from Stockholders & .099 & .110 \\
\hline Other Liabilities & .122 & .129 \\
\hline
\end{tabular}

Notes: This information is taken from the 5471 forms of the controlled foreign subsidiaries filed by nonfinancial parents. Number of observations $=5,981$. See the text for details. 
Table 2

The Effect of Taxes on Financial Assets Held by CFCs

(Dependent variable $=$ Asset Item/Total CFC Assets)

\begin{tabular}{|c|c|c|c|c|c|c|c|}
\hline Asset Item/Total CFC Assets & $\begin{array}{l}\text { Age Less } \\
\text { Than } \\
5 \text { Years } \\
\end{array}$ & $\begin{array}{l}\text { Age 5-15 } \\
\text { Years }\end{array}$ & $\begin{array}{l}\text { Dividend } \\
\text { Tax in } \\
\text { Excess } \\
\text { Limit } \\
\end{array}$ & $\begin{array}{l}\text { Withholding } \\
\text { Tax Rate } \\
\text { On } \\
\text { Dividends } \\
\end{array}$ & $\begin{array}{c}\text { Statutory } \\
\text { Tax } \\
\text { Rate } \\
\end{array}$ & $\begin{array}{c}\text { Excess } \\
\text { Limit Dividend } \\
\text { Tax*Overall Foreign } \\
\text { Tax Rate } \\
\end{array}$ & $\begin{array}{c}\text { Current Year } \\
\text { Earnings and } \\
\text { Profits/Total } \\
\text { Assets } \\
\end{array}$ \\
\hline Passive Assets & $\begin{array}{l}.011 \\
(1.38)\end{array}$ & $\begin{array}{l}.020 \\
(2.98)\end{array}$ & $\begin{array}{l}.140 \\
(5.13)\end{array}$ & $\begin{array}{l}-.032 \\
(1.00)\end{array}$ & & & \\
\hline Investment in Subsidiaries & $\begin{array}{c}.043 \\
(4.23)\end{array}$ & $\begin{array}{l}.006 \\
(.71)\end{array}$ & $\begin{array}{c}.131 \\
(3.98)\end{array}$ & $\begin{array}{l}-.287 \\
(7.55)\end{array}$ & & & \\
\hline Loans to Affiliates & $\begin{array}{c}.023 \\
(2.89) \\
\end{array}$ & $\begin{array}{c}.032 \\
(5.06) \\
\end{array}$ & $\begin{array}{r}.139 \\
(5.40) \\
\end{array}$ & $\begin{array}{l}-.035 \\
(1.17) \\
\end{array}$ & & & \\
\hline Passive Assets & $\begin{array}{l}.010 \\
(1.25)\end{array}$ & $\begin{array}{l}.020 \\
(2.95)\end{array}$ & $\begin{array}{l}-.154 \\
(3.48)\end{array}$ & $\begin{array}{l}-.107 \\
(3.30)\end{array}$ & $\begin{array}{l}-.347 \\
(8.40)\end{array}$ & & \\
\hline Investment in Subsidiaries & $\begin{array}{c}.043 \\
(4.31)\end{array}$ & $\begin{array}{l}.006 \\
(.74)\end{array}$ & $\begin{array}{l}.333 \\
(6.21)\end{array}$ & $\begin{array}{l}-.234 \\
(5.95)\end{array}$ & $\begin{array}{c}.238 \\
(4.77)\end{array}$ & & \\
\hline Loans to Affiliates & $\begin{array}{c}.023 \\
(2.92) \\
\end{array}$ & $\begin{array}{c}.032 \\
(5.07) \\
\end{array}$ & $\begin{array}{r}.199 \\
(4.76) \\
\end{array}$ & $\begin{array}{l}-.019 \\
(.62)\end{array}$ & $\begin{array}{c}.071 \\
(1.83) \\
\end{array}$ & & \\
\hline Passive Assets & $\begin{array}{l}.001 \\
(.100)\end{array}$ & $\begin{array}{l}.015 \\
(2.29)\end{array}$ & $\begin{array}{l}.153 \\
(3.33)\end{array}$ & $\begin{array}{l}-.024 \\
(.77)\end{array}$ & & $\begin{array}{l}-.278 \\
(2.37)\end{array}$ & \\
\hline Investment in Subsidiaries & $\begin{array}{l}.039 \\
(3.10)\end{array}$ & $\begin{array}{l}-.003 \\
(.350)\end{array}$ & $\begin{array}{l}.164 \\
(2.47)\end{array}$ & $\begin{array}{l}-.271 \\
(5.91)\end{array}$ & & $\begin{array}{l}-.046 \\
(.27)\end{array}$ & \\
\hline Loans to Affiliates & $\begin{array}{c}.035 \\
(3.49) \\
\end{array}$ & $\begin{array}{r}.041 \\
(5.29) \\
\end{array}$ & $\begin{array}{r}.288 \\
(5.39) \\
\end{array}$ & $\begin{array}{l}-.066 \\
(1.80)\end{array}$ & & $\begin{array}{l}-.367 \\
(2.70)\end{array}$ & \\
\hline $\begin{array}{l}\text { Accumulated Earnings and } \\
\text { Profits }\end{array}$ & $\begin{array}{c}-.146 \\
(7.65) \\
\end{array}$ & $\begin{array}{c}-.079 \\
(11.71) \\
\end{array}$ & $\begin{array}{r}.159 \\
(5.76) \\
\end{array}$ & $\begin{array}{c}.244 \\
(7.65) \\
\end{array}$ & & & $\begin{array}{c}.324 \\
(16.58) \\
\end{array}$ \\
\hline
\end{tabular}

Notes: The sample includes all CFCs of non-financial parents $(\mathrm{N}=5,981)$. The columns report OLS coefficients with t-values in parentheses. The adjusted R-squared for all of the regressions were below .15 and many were much lower. Except for the regression in the bottom row of the table, all means of the dependent variables are reported in table 1 . The mean of accumulated earnings and profits for all CFCs of non-financial parents is .139. In the third set of regressions using the overall foreign tax rate on repatriated income interacted with the excess limit dividend tax rate, there are 3,983 observations. The overall foreign tax rate is the ratio of foreign taxes paid on repatriated income to the MNC's total net foreign source income. 
Table 3

The Effect of Dividend Repatriation Taxes on Dividends Paid to Foreign Affiliates (Dependent Variable $=$ Dividends Paid to Foreign Affiliates/Total Dividends)

\begin{tabular}{lcc}
\hline & All CFCs & Non-financial CFCs \\
\hline Excess Limit Tax on Dividends & .208 & .285 \\
& $(2.22)$ & $(2.75)$ \\
Withholding Tax on Dividends & -.727 & -.761 \\
& $(6.20)$ & $(5.48)$ \\
Subpart F Income/CFC Assets & -.098 & -.088 \\
& $(1.96)$ & $(1.64)$ \\
Ages less than 5 years & .087 & .192 \\
& $(2.24)$ & $(3.46)$ \\
Age 5-15 years & .063 & .087 \\
& $(2.53)$ & $(2.91)$ \\
\hline Mean of Dependent Variable & & .412 \\
Number of observations & .429 & 1,348 \\
Adjusted R squared & 1,890 & .0396 \\
\hline
\end{tabular}

Note: The columns report OLS coefficients with t-values in parentheses. 
Table 4

The Effect of Taxes on CFC Debt

(Dependent variable $=$ Liability Item/Total CFC Assets)

\begin{tabular}{|c|c|c|c|c|c|c|c|c|}
\hline$\frac{\text { Liability Item }}{\text { Total CFC Assets }}$ & $\begin{array}{l}\text { Age Less } \\
\text { Than } \\
5 \text { Years }\end{array}$ & $\begin{array}{c}\text { Age } \\
1-15 \\
\text { Years }\end{array}$ & $\begin{array}{l}\text { Statutory } \\
\text { Tax Rate }\end{array}$ & $\begin{array}{c}\text { Withholding } \\
\text { Tax Rate on } \\
\text { Interest }\end{array}$ & $\begin{array}{l}\text { Accumulated } \\
\text { Earnings }\end{array}$ & $\begin{array}{c}\text { Excess } \\
\text { Limit } \\
\text { Tax on } \\
\text { Dividends }\end{array}$ & $\begin{array}{c}\text { Accumulated } \\
\text { Earnings and } \\
\text { Profits* Excess } \\
\text { Limit Tax }\end{array}$ & $\begin{array}{c}\text { Withholding } \\
\text { Tax Rate on } \\
\text { Dividends }\end{array}$ \\
\hline All CFC Debt & $\begin{array}{c}-.015 \\
(1.33)\end{array}$ & $\begin{array}{c}-.011 \\
(1.30)\end{array}$ & $\begin{array}{c}.393 \\
(11.77)\end{array}$ & $\begin{array}{r}-.036 \\
(.68)\end{array}$ & & & & \\
\hline $\begin{array}{l}\text { Loans from Related } \\
\text { Parties }\end{array}$ & $\begin{array}{l}.046 \\
(5.71)\end{array}$ & $\begin{array}{c}.029 \\
(4.46)\end{array}$ & $\begin{array}{l}.065 \\
(2.65)\end{array}$ & $\begin{array}{l}-.119 \\
(3.00)\end{array}$ & & & & \\
\hline Third Party Debt & $\begin{array}{l}-.061 \\
(5.44)\end{array}$ & $\begin{array}{l}-.018 \\
(1.95)\end{array}$ & $\begin{array}{l}.328 \\
(9.64)\end{array}$ & $\begin{array}{c}.082 \\
(1.51)\end{array}$ & & & & \\
\hline All CFC Debt & $\begin{array}{l}-.064 \\
(5.84)\end{array}$ & $\begin{array}{l}-.014 \\
(1.65)\end{array}$ & $\begin{array}{l}.126 \\
(2.36)\end{array}$ & $\begin{array}{l}.068 \\
(1.08)\end{array}$ & $\begin{array}{l}-.245 \\
(9.03)\end{array}$ & $\begin{array}{l}-.182 \\
(3.00)\end{array}$ & $\begin{array}{l}-.431 \\
(3.01)\end{array}$ & $\begin{array}{l}-.077 \\
(1.52)\end{array}$ \\
\hline $\begin{array}{l}\text { Loans from Related } \\
\text { Parties }\end{array}$ & $\begin{array}{c}.024 \\
(2.91)\end{array}$ & $\begin{array}{c}.018 \\
(2.78)\end{array}$ & $\begin{array}{l}.141 \\
(3.51)\end{array}$ & $\begin{array}{l}-.108 \\
(2.27)\end{array}$ & $\begin{array}{l}-.124 \\
(6.08)\end{array}$ & $\begin{array}{l}.155 \\
(3.40)\end{array}$ & $\begin{array}{r}-.055 \\
(.51)\end{array}$ & $\begin{array}{c}.056 \\
(1.48)\end{array}$ \\
\hline Third Party Debt & $\begin{array}{l}-.088 \\
(7.74)\end{array}$ & $\begin{array}{l}-.032 \\
(3.60)\end{array}$ & $\begin{array}{l}-.015 \\
(.27)\end{array}$ & $\begin{array}{l}.176 \\
(2.69)\end{array}$ & $\begin{array}{l}-.121 \\
(4.29)\end{array}$ & $\begin{array}{l}-.337 \\
(5.36)\end{array}$ & $\begin{array}{l}-.377 \\
(2.53)\end{array}$ & $\begin{array}{l}-.133 \\
(2.53)\end{array}$ \\
\hline
\end{tabular}

Note: The sample includes all CFCs of non-financial parents $(\mathrm{N}=5,981)$. The columns report OLS coefficients with $\mathrm{t}$-values in parentheses. All of the regressions had adjusted R-squareds of less than .10. 